DOE/ID-10679

Revision 1

September 2003

Project No. 23339

\title{
New Pump and Treat Facility Remedial Action Work Plan for Test Area North Final Groundwater Remediation, Operable Unit 1-07B
}


DOE/ID-10679

Revision 1

\section{New Pump and Treat Facility Remedial Action Work Plan for Test Area North Final Groundwater Remediation, Operable Unit 1-07B}

September 2003

Prepared for the 


\title{
New Pump and Treat Facility Remedial Action Work Plan for Test Area North Final Groundwater Remediation, Operable Unit 1-07B
}

\author{
DOE/ID-10679
}

Revision 1

September 2003

Approved by

Lee O. Nelson

Date

OU 1-07B Project Manager

Doug Vandel

OU 1-07B Project Engineer 


\begin{abstract}
This remedial action work plan identifies the approach and requirements for implementing the medial zone remedial action for Test Area North, Operable Unit 1-07B, at the Idaho National Engineering and Environmental Laboratory. This plan details the management approach for the construction and operation of the New Pump and Treat Facility. As identified in the remedial design/remedial action scope of work, a separate remedial design/remedial action work plan will be prepared for each remedial component of the Operable Unit 1-07B remedial action.

This work plan was originally prepared as an early implementation of the final Phase $\mathrm{C}$ remediation. At that time, the Phase $\mathrm{C}$ implementation strategy was to use this document as the overall Phase C Work Plan and was to be revised to include the remedial actions for the other remedial zones (hotspot and distal zones). After the completion of Record of Decision Amendment: Technical Support Facility Injection Well (TSF-05) and Surrounding Groundwater Contamination (TSF-23) and Miscellaneous No Action Sites, Final Remedial Action, it was determined that each remedial zone would have its own stand-alone remedial action work plan. Revision 1 of this document converts this document to a stand-alone remedial action work plan specific to the implementation of the New Pump and Treat Facility used for plume remediation within the medial zone of the OU 1-07B contaminated plume.
\end{abstract}




\section{CONTENTS}

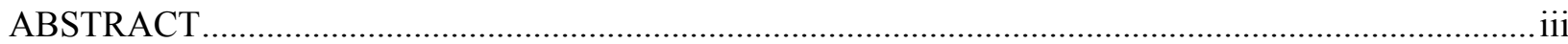

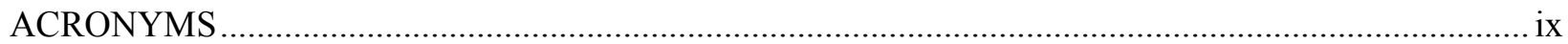

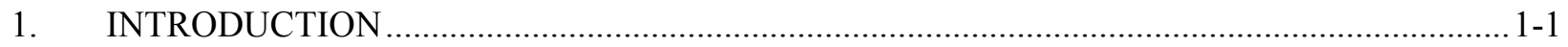

1.1 Overall Remedial Action Summary ….................................................................. 1-1

1.2 New Pump and Treat Facility Remedial Action Approach............................................. 1-2

1.2.1 Medial Zone Implementation Activities .......................................................... 1-3

1.2.2 ROD Amendment Implementation Changes .................................................... 1-4

1.3 Medial Zone-New Pump and Treat Facility ............................................................... 1-5

1.3.1 New Pump and Treat Facility System Description ............................................. 1-5

1.3.2 New Pump and Treat Facility Process System Requirements ............................... 1-5

$1.4 \quad$ Performance and Compliance Monitoring .................................................................... 1-7

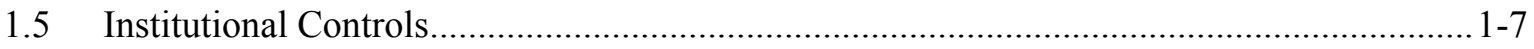

2. REMEDIAL ACTION OBJECTIVES AND AGENCY REVIEW OF REMEDY

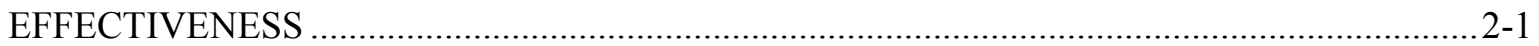

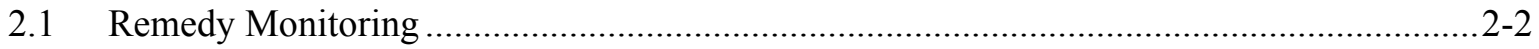

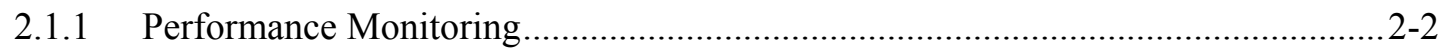

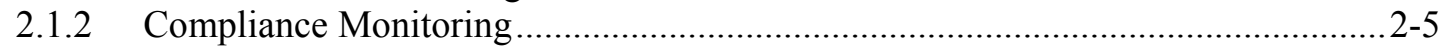

2.2 Remedy Performance Review and Closure........................................................ 2-6

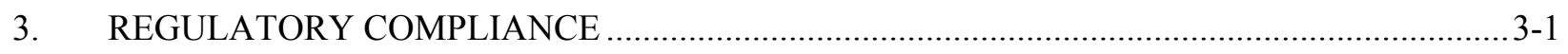

3.1 Compliance with Applicable or Relevant and Appropriate Requirements ......................... 3-1

3.2 Environmental Compliance ................................................................................

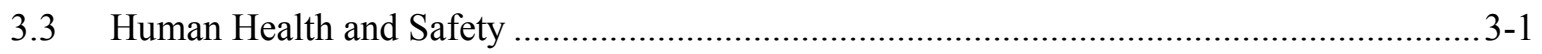

3.4 U.S. Department of Energy Orders ....................................................................... 3-1

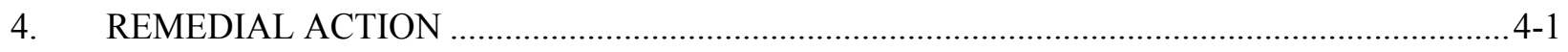

4.1 Facility Procurement and Construction .................................................................

4.1.1 Project Management and Construction Management ............................................. 4-1

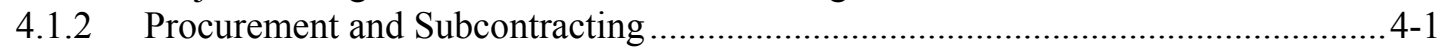

4.1.3 Construction Activities ............................................................................................ 


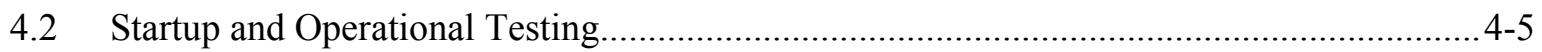

4.3 Prefinal Inspection Activities ...................................................................................... 4-5

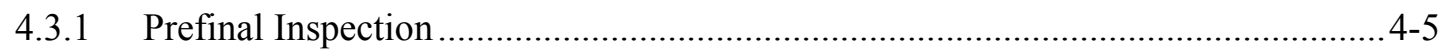

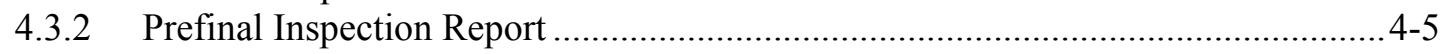

4.4 Final Inspection Activities ......................................................................................

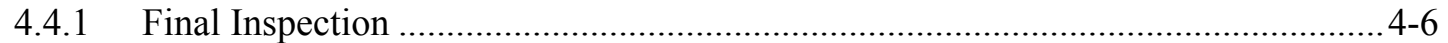

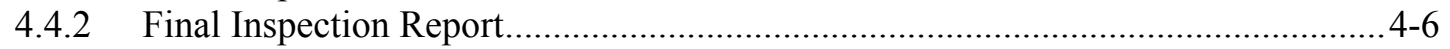

4.5 Initial Operations and Shakedown Period................................................................... 4-6

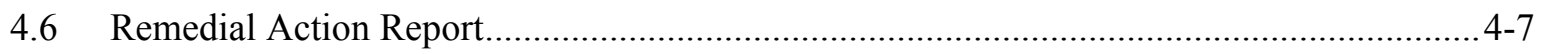

5. OPERATIONS AND MAINTENANCE …............................................................................

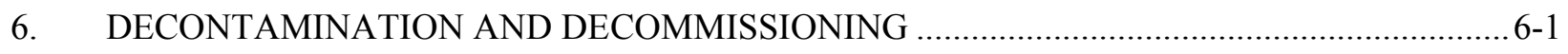

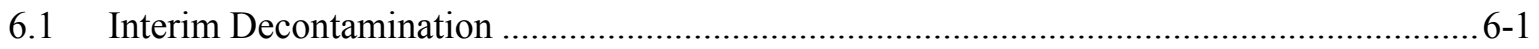

6.2 Final Decontamination and Decommissioning .......................................................... 6-1

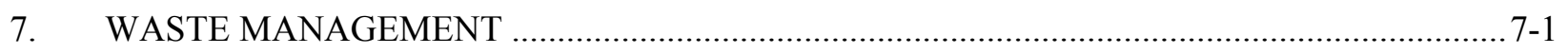

7.1 Resource Conservation and Recovery Act Listed Waste.............................................. 7-1

7.1.1 Listed Waste Determination ......................................................................... $7-1$

7.1.2 No-Longer-Contained-In Determination ...................................................

7.2 Toxic Substances and Control Act Regulated Wastes .................................................. 7-2

7.3 Low-Level Radioactive Waste ............................................................................... $7-2$

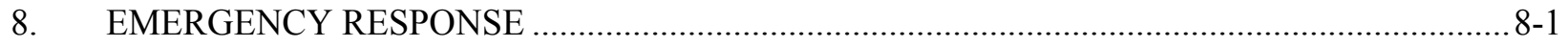

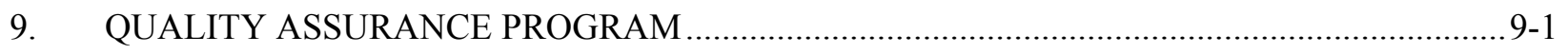

10. SAFETY AND HEALTH PROGRAM ......................................................................... 10-1

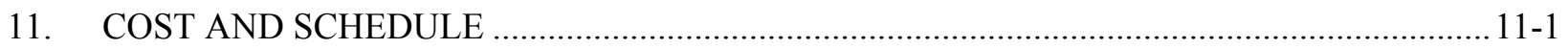

11.1 Record of Decision Cost versus Current Baseline ..................................................... 11-1

11.2 New Pump and Treat Facility Construction Estimate ............................................... 11-2

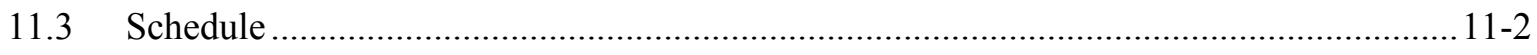

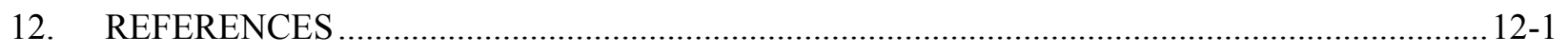

Appendix A —Compliance with Regulatory Requirements.............................................................. A-1

Appendix B-Agency Phase C Document Review Comments and Resolutions .................................... B-1 


\section{FIGURES}

1-1. Operable Unit 1-07B trichloroethene contaminant plume..................................................... 1-3

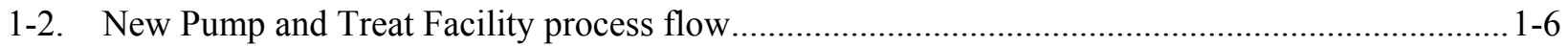

4-1. Agency remedial action acceptance logic diagram ............................................................... 4-2

11-1. New Pump and Treat Facility construction schedule ….......................................................11-4

TABLES

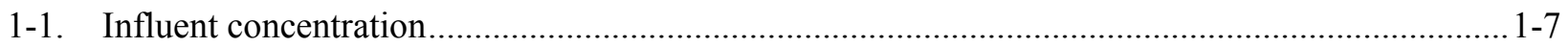

2-1. Operable Unit 1-07B groundwater remediation remedy monitoring crosswalk table..................2-3

2-2. New Pump and Treat Facility performance monitoring / compliance monitoring criterion ...........2-4

2-3. New Pump and Treat Facility drawdown measurement wells .................................................2-5

3-1. Summary of applicable or relevant and appropriate requirements for remedial action.................. 3-2

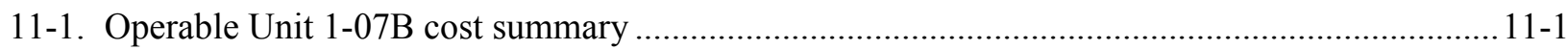

11-2. New Pump and Treat Facility 90\% construction cost estimate ............................................... 11-2

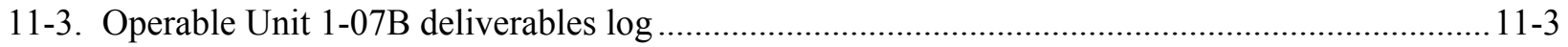




\section{ACRONYMS}

ANP aircraft nuclear propulsion

ARAR applicable or relevant and appropriate requirements

ASTU Air Stripper Treatment Unit

BLM Bureau of Land Management

CERCLA Comprehensive Environmental Response, Compensation, and Liability Act

CFR Code of Federal Regulations

COC contaminants of concern

CWSU CERCLA waste storage unit

D\&D decontamination and decommissioning

DCE dichloroethene

DEQ Idaho Division of Environmental Quality

DOE U.S. Department of Energy

DOE-ID U.S. Department of Energy Idaho Operations Office

EA emergency action

EPA U.S. Environmental Protection Agency

ESD explanation of significant differences

FDR field demonstration report

FFA/CO Federal Facility Agreement and Consent Order

GWTF Groundwater Treatment Facility

HASP Health and Safety Plan

HWMA Hazardous Waste Management Act

IDAPA Idaho Administrative Procedures Act

INEEL Idaho National Engineering and Environmental Laboratory

ISB in situ bioremediation

ISCO in situ chemical oxidation 


\begin{tabular}{|c|c|}
\hline ISMS & Integrated Safety Management System \\
\hline LDR & land disposal restrictions \\
\hline $\mathrm{M} \& \mathrm{O}$ & management and operating \\
\hline MCL & maximum contaminant level \\
\hline MNA & monitored natural attenuation \\
\hline MSA & management self-assessments \\
\hline NA & natural attenuation \\
\hline NCP & National Oil and Hazardous Substances Pollution Contingency Plan \\
\hline NEPA & National Environmental Policy Act \\
\hline NESHAPS & National Emissions Standards for Hazardous Air Pollutants \\
\hline $\mathrm{NIH}$ & normal industrial hazard \\
\hline NLCID & no-longer contained-in determination \\
\hline NPTF & New Pump and Treat Facility \\
\hline O\&M & operations and maintenance \\
\hline OM\&M & operations, monitoring and maintenance \\
\hline OSHA & Occupational Safety and Health Administration \\
\hline OU & operable unit \\
\hline PCB & polychlorinated biphenyl \\
\hline PCE & tetrachloroethene \\
\hline $\mathrm{PM} / \mathrm{CM}$ & performance/compliance monitoring \\
\hline RAO & remedial action objective \\
\hline RAWP & remedial action work plan \\
\hline RCRA & Resource Conservation and Recovery Act \\
\hline $\mathrm{RD} / \mathrm{RA}$ & remedial design/remedial action \\
\hline $\mathrm{RI} / \mathrm{FS}$ & remedial investigation/feasibility study \\
\hline ROD & Record of Decision \\
\hline
\end{tabular}


SOW Scope of Work

TAN Test Area North

TCE trichloroethene

TEWP technology evaluation work plan

TSCA Toxic Substances and Control Act

TSF Technical Support Facility

VOC volatile organic compound

VPP Voluntary Protection Program

WAG waste area group

WCE well characterization and evaluation

WMP Waste Management Plan 


\section{New Pump and Treat Facility Remedial Action Work Plan for Test Area North Final Groundwater Remediation, Operable Unit 1-07B}

\section{INTRODUCTION}

This remedial action work plan (RAWP) is prepared in accordance with the Federal Facility Agreement and Consent Order for the Idaho National Engineering Laboratory (DOE-ID 1991) by the U.S. Department of Energy Idaho Operations Office (DOE-ID). This plan addresses the implementation of the medial zone remedial component (New Pump and Treat Facility [NPTF]) of the Operable Unit (OU) 1-07B remedial action at Test Area North (TAN) Technical Support Facility (TSF) injection well, TSF-05; and surrounding groundwater contamination, TSF-23. This Comprehensive Environmental Response, Compensation, and Liability Act (CERCLA) (42 USC\$9601 et seq.) remedial action will proceed in accordance with the signed Record of Decision, Declaration for the Technical Support Facility Injection Well (TSF-05) and Surrounding Groundwater Contamination (TSF-23) and Miscellaneous No Action Sites Final Remedial Action, Operable Unit 1-07B, Waste Area Group 1 (DOE-ID 1995), hereinafter referred to as the OU 1-07B or 1995 Record of Decision (ROD); and in accordance with the signed Record of Decision Amendment: Technical Support Facility Injection Well (TSF-05) and Surrounding Groundwater Contamination (TSF-23) and Miscellaneous No Action Sites, Final Remedial Action (DOE-ID 2001b), hereinafter referred to as the OU 1-07B or 2001 ROD Amendment.

The scope of the complete OU 1-07B final remedial action is described in the remedial design/remedial action (RD/RA) scope of work (SOW), which includes the Remedial Design Remedial Action Scope of Work Test Area North Final Groundwater Remediation Operable Unit 1-07B (DOE-ID 1997b) and Remedial Design/Remedial Action Scope of Work (DOE-ID 2001a).

The OU 1-07B ROD states that the selected remedy will be conducted in three phases, as follows: (1) Phase A-Transition of OU 1-07A Interim Action to OU 1-07B Final Remedial Action, (2) Phase B-Hot Spot Containment and/or Removal with Treatability Studies, and (3) Phase C-Dissolved Phase Groundwater Treatment with Continuation of Hot Spot Containment and/or Removal. The Phase A transition period was completed in 1995, and signified the end of the OU 1-07A interim action.

During Phase B, the Groundwater Treatment Facility (GWTF) was operated to provide source containment. Treatability studies were also conducted which showed that the use of monitored natural attenuation (MNA) and in situ bioremediation (ISB), in combination with pump-and-treat, could clean up the contaminant plume in less time and at a lower cost than the original remedy selected in the 1995 ROD. The 2001 ROD Amendment documents these changes and has been approved by the regulating agencies. Based on the approval of the ROD Amendment, Phase B has officially been completed and the project now is into full-scale implementation of Phase C.

Prior to the completion of Phase B, "early implementation of Phase C" began with the construction of the New Pump and Treat Facility (NPTF), which is used to treat groundwater from within the medial zone.

\subsection{Overall Remedial Action Summary}

Phase $\mathrm{C}$ represents the final implementation of the remedial actions selected for each of the remedial zones within the OU 1-07B contaminated plume. The final remedy is required to be complete in no more than 100 years from the original ROD signature date, and will end when the National Oil and 
Hazardous Substances Pollution Contingency Plan (NCP) review process demonstrates that remedial action objectives (RAOs) have been met.

As described in the Explanation of Significant Differences from the Record of Decision for the Technical Support Facility Injection Well (TSF-05) and Surrounding Groundwater Contamination (TSF-23) and Miscellaneous No Action Sites, Final Remedial Action, Operable Unit 1-07B, Waste Area Group 1, Idaho National Engineering and Environmental Laboratory (INEEL 1997b) and the associated RD/RA SOW (DOE-ID 1997b), the final remedy assumed implementation of the default pump and treat remedy to include separate pump and treat systems in each of the three treatment zones. The three zones are shown in Figure 1-1 and are defined based on the 1997 trichloroethene (TCE) concentration as follows:

- $\quad$ Hot spot (greater than $20,000 \mu \mathrm{g} / \mathrm{L}$ TCE)

- $\quad$ Medial zone (dissolved phase 1,000 to $20,000 \mu \mathrm{g} / \mathrm{L}$ TCE)

- $\quad$ Distal zone (dissolved phase 5 to $1,000 \mu \mathrm{g} / \mathrm{L}$ TCE).

Based on the treatability studies, and as agreed to in the 2001 ROD Amendment (DOE ID 2001b), the final remedy replaced the pump and treat systems that were to be placed in the hot spot and distal zones with alternative technologies. The final selected technologies to be used for the final remedial actions were changed to the following:

- Hot spot - In situ bioremediation (ISB)

- $\quad$ Medial zone-Pump and treat (using the NPTF)

- Distal zone-Monitored natural attenuation (MNA).

At the time of the 2001 ROD Amendment, it was determined that separate work plans would be prepared for each of the different treatment zones. This work plan will provide the controlling documents for the medial zone (New Pump and Treat Facility).

\subsection{New Pump and Treat Facility Remedial Action Approach}

A separate remedial design, the New Pump and Treat Facility Remedial Design Test Area North Operable Unit 1-07B(DOE-ID 2000), was prepared and approved by the Agencies (i.e., DOE-ID, U.S. Environmental Protection Agency [EPA], and Idaho Department of Environmental Quality [DEQ]), specifying the configuration of the NPTF. The remedial design and RAWP are built upon the planning elements established in the RD/RA SOW and Explanation of Significant Differences (ESD) (DOE-ID 1997b, INEEL 1997b), and they carry those elements through the design and implementation of the remedy. Supporting the remedial design and RAWP are associated documents including the New Pump and Treat Facility Operations and Maintenance Plan for Test Area North Groundwater Remediation Operable Unit 1-07B (DOE-ID 2003a), the Sampling and Analysis Plan (SAP) (Appendix A of the NPTF Operations and Maintenance [O\&M] Plan), Waste Management Plan for Test Area North Final Groundwater Remediation (INEEL 2002a), Interim Decontamination Plan for Operable Unit 1-07B (INEEL 2002b), and the approved Health and Safety Plan (HASP)-Test Area North Operable Unit 1-07B Final Groundwater Remedial Action Health and Safety Plan (INEEL 2002c). 


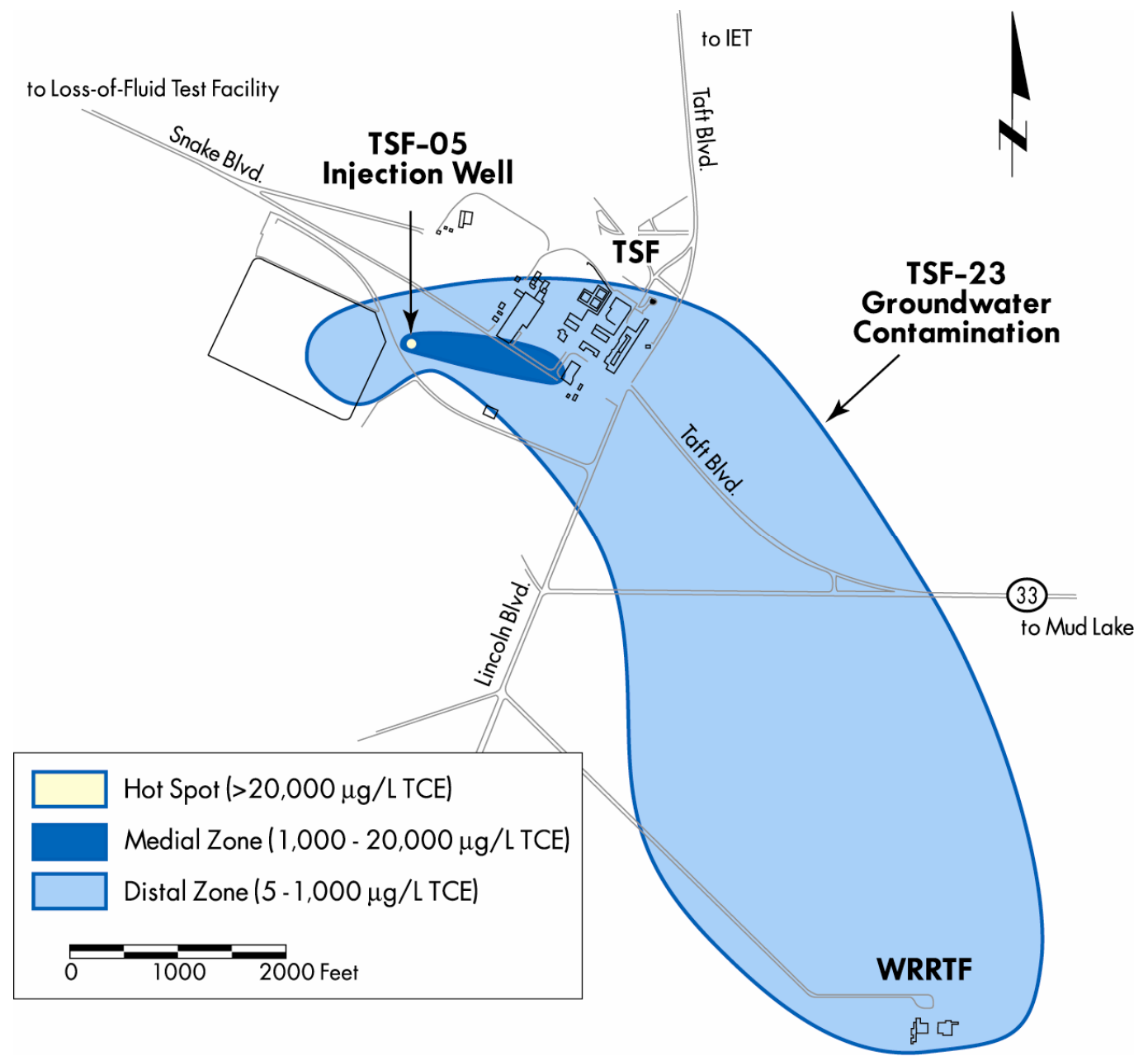

Figure 1-1. Operable Unit 1-07B trichloroethene contaminant plume.

Implementation of the remedial action for the medial zone was initiated through the design, construction, and operation of the NPTF. As described in the ESD, the construction and operation of the NPTF was considered early implementation of Phase C.

\subsubsection{Medial Zone Implementation Activities}

The planned medial zone remedial activities are identified below. The activities under item 1 are addressed in this RAWP, and the activities under Items 2 through 6 are addressed in the NPTF O\&M Plan (DOE-ID 2003a) as long-term O\&M activities:

1. New facility construction-NPTF:
a. Design
b. Construction
c. Startup, system operational (SO) testing, and agency prefinal inspection 

d. Initial operations and shakedown
e. Final inspection and remedial action report.

2. NPTF:
a. Operations and maintenance
b. Compliance inspection
c. Waste management.

3. Remedy performance monitoring:
a. Compliance monitoring
b. Long-term performance monitoring (remedial action objective performance evaluation-support site conceptual model update)
c. Groundwater monitoring (plume dynamics monitoring).

4. Five-year reviews and O\&M report:
a. Five-year reviews
b. O\&M Report.

5. Institutional controls.

6. Decontamination and dismantlement.

\subsubsection{ROD Amendment Implementation Changes}

The ROD Amendment (DOE-ID 2001b) for the OU 1-07B remedial action was developed and approved in 2001. With this amendment, the following applicable or relevant and appropriate requirements (ARARs) previously applicable to the NPTF were deleted because they no longer apply:

- $\quad 40$ CFR 264, Subpart X, Miscellaneous Units

- $\quad 40$ CFR Subpart AA, Air Emission Standards for Process Vents

- $\quad$ DOE Order 5480.7A, Fire Protection. DOE Order 5480.7A was cancelled by DOE. It has been superseded by DOE 420.1, Facility Safety. Appropriate measures will be taken for worker safety.

- $\quad$ DOE Order 5820.2A, Radioactive Waste Management. DOE Order 5820.2A was canceled by DOE Order 435.1, Radioactive Waste Management, on July 9, 1999.

In addition to the deleted ARARs, the following clarifications were made as to the application of ARARs to NPTF operations:

- $\quad$ The Agencies do not intend to reinject radionuclides above maximum contaminant levels (MCLs) 
- The TCE in the contaminated groundwater is a listed waste. Therefore, all components on the influent side of the treatment system, including the air stripper equipment, have been designed to meet the secondary containment requirements of Code of Federal Regulations (CFR) 40 CFR 264, Subpart J, of the Resource Conservation and Recovery Act (RCRA). After the air stripping process, the concentrations of hazardous constituents in groundwater will be less than the applicable MCL and will result in a cumulative carcinogenic risk of less than $1 \times 10^{-5}$. As a result, a no-longer-contained-in determination is applicable and the NPTF effluent is no longer considered a listed hazardous waste.

\subsection{Medial Zone-New Pump and Treat Facility}

The medial zone remediation includes operation of the NPTF with extraction wells located approximately $610 \mathrm{~m}(2,000 \mathrm{ft})$ downgradient from the TSF-05 injection well. The purpose of the NPTF is to capture and treat groundwater between the hot spot containment zone and the medial zone extraction wells. The facility operates at between 454 and $946 \mathrm{~L} / \mathrm{min}(120$ and $250 \mathrm{gpm})$. Based on data collected at the extraction location, influent radionuclide concentrations are below maximum contaminant levels (MCLs), and thus the system does not require radionuclide removal treatment.

\subsubsection{New Pump and Treat Facility System Description}

The NPTF consists of the equipment and piping needed to pump water from Wells TAN-38, -39 and -40 , process the water through two parallel air stripper treatment trains with a maximum capacity of $473 \mathrm{~L} / \mathrm{min}$ (125 gpm) each, and discharge the effluent water into a downgradient injection well (TAN-53A). The system pumps water from a combination of the wells at a minimum flow rate of $454 \mathrm{~L} / \mathrm{min}(120 \mathrm{gpm})$. This water is treated, using air strippers, to below MCLs for volatile organic compounds (VOCs). The extracted groundwater is considered F001-listed waste and all components of the extraction system will meet secondary containment requirements required by 40 CFR 264 Subpart J. After the air stripping process, the water is (through approval of the DEQ) considered to no longer contain the listed hazardous waste and is discharged to the injection well without having to comply with the secondary containment requirements.

\subsubsection{New Pump and Treat Facility Process System Requirements}

The NPTF process flow is depicted in Figure 1-2. The following is a summary of design parameters established as functional and operational requirements used during the design of the NPTF:

- $\quad$ The system will pump and treat water at a normal minimum operating flow rate of $454 \mathrm{~L} / \mathrm{min}$ (120 gpm), with the capability for processing up to $946 \mathrm{~L} / \mathrm{min}$ (250 gpm).

- $\quad$ The system will be capable of extracting water separately or in combination from any of the Wells TAN-38, -39 , and -40 . The water will be reinjected into a new downgradient well.

- $\quad$ The system will operate 24 hours/day, 7 days/week, while maintaining a facility uptime of $\geq 90 \%$ over a one-year period.

- $\quad$ The system will be designed for unmanned operation. For design purposes, the maximum length of time needed for unmanned operations is 4 days.

- $\quad$ The facility will have a 25-year design life. (The facility will be replaced as necessary thereafter.) 


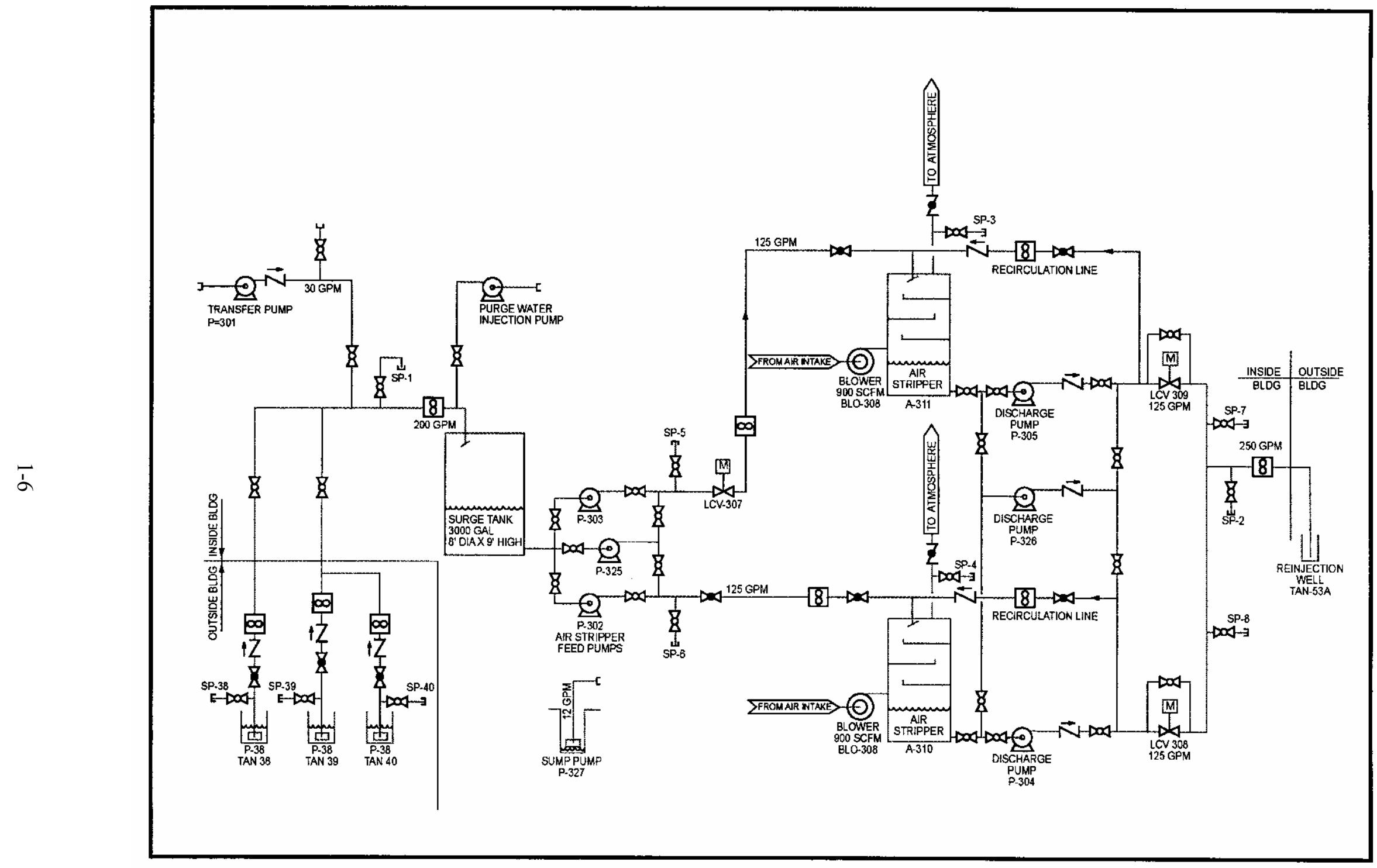

Figure 1-2. New Pump and Treat Facility process flow. 
- The air stripper must remove the VOCs in the extracted water to below the set MCL. Based on the sampling results obtained during the well characterization and evaluation activities, the design influent concentrations for VOCs are as shown in Table 1-1 (INEEL 1998). In order to meet MCLs, the air stripper must obtain a minimum removal efficiency of $99.6 \%$.

- The VOC's remaining in the effluent water must result in a cumulative carcinogenic risk less than $1 \times 10^{-5}$.

- $\quad$ The system will not provide treatment for radionuclide removal.

\subsection{Performance and Compliance Monitoring}

The purpose of performance and compliance monitoring is to monitor the contaminants of concern (COC) concentration changes over time, verify compliance with the ARARs, and evaluate attainment of RAOs. The scope and requirements for performance and compliance monitoring in the medial zone are addressed in the NPTF O\&M Plan (DOE-ID 2003a).

Water monitoring for the NPTF will be performed in accordance with the SAP (Appendix A of the O\&M Plan [DOE-ID 2003a]) developed for the NPTF. The NPTF SAP will consider and support the RAOs identified in the ROD Amendment (DOE-ID 2001b) specific to ARAR compliance for the NPTF. The Monitored Natural Attenuation Operations, Monitoring, and Maintenance Plan for Test Area North, Operable Unit 1-07B (DOE-ID 2003b) will support upgradient source control monitoring. Data obtained from MNA monitoring will be used to evaluate the presence of upgradient anomalies that could possibly impact NPTF operations.

\subsection{Institutional Controls}

Institutional controls will consist of engineering and administrative controls to protect current and future users from health risks associated with groundwater contamination by preventing ingestion of groundwater having concentrations of COCs exceeding MCLs or a cumulative risk level of $1 \times 10^{-4}$. The scope and requirements for institutional controls are addressed in Section 6 of the NPTF O\&M Plan (DOE-ID 2003a).

Table 1-1. Influent concentration.

\begin{tabular}{llrr}
\hline Contaminant & $\begin{array}{r}\text { Concentration } \\
(\mu \mathrm{g} / \mathrm{L})\end{array}$ & $\begin{array}{r}\text { MCL } \\
(\mu \mathrm{g} / \mathrm{L})\end{array}$ \\
& TCE & 1,100 & 5 \\
& PCE & 70 & 5 \\
& Cis-DCE & 120 & 70 \\
& Trans-DCE & 50 & 100 \\
MCL $=$ & maximum contaminant level & & \\
TCE $=$ & trichloroethene & & \\
PCE $=$ & tetrachloroethene & dichloroethene. &
\end{tabular}




\section{REMEDIAL ACTION OBJECTIVES AND AGENCY REVIEW OF REMEDY EFFECTIVENESS}

As part of the remedial investigation/feasibility study (RI/FS) process, RAOs were developed in accordance with the NCP and EPA guidance for conducting RI/FS investigations. The purpose of the objectives is to reduce the contamination in the groundwater at TAN to ensure that off-Site populations are not at risk in the future, and that future residents would not be at risk from use of TAN groundwater if the TAN area were converted to the public domain at any time in the future. The RAOs for Phase C, as specified in the 1-07B 1995 ROD, include:

- $\quad$ Prevent, to the maximum extent practicable, migration of contaminated groundwater beyond the hot spot at levels above MCLs, or for those contaminants for which an MCL does not exist, the contaminant concentration will be such that the total excess cancer risk posed by release of contaminated groundwater will be within the acceptable range of 1.0E-04 to $1.0 \mathrm{E}-06$. For above-ground treatment processes using reinjection of treated effluent, treatment shall, at a minimum, be sufficient to reduce the VOC concentration to below MCLs. The VOCs discharged to the atmosphere from hot spot treatment operations will not exceed the calculated emission rate limits specified in Table 9-1 of the 1995 ROD (DOE-ID 1995).

- $\quad$ Capture and treat a sufficient portion of the dissolved phase plume beyond the hot spot to provide for aquifer cleanup within 100 years of the date of the ROD signature. For above-ground treatment processes using reinjection of treated effluent, treatment shall be designed to reduce the VOC concentration to below MCLs. If an MCL does not exist, the contaminant concentration will be such that the total excess cancer risk posed by the groundwater will be within the acceptable range of 1.0E-04 to 1.0E-06. The VOCs discharged to the atmosphere from GWTF operations will not exceed the calculated emission rate limits specified in Table 9-1 of the 1995 ROD.

- Institutional controls shall be implemented to protect current and future users from health risks associated with ingestion of groundwater containing COC concentrations greater than MCLs or $1.0 \mathrm{E}-04$ to $1.0 \mathrm{E}-06$ risk-based concentrations for contaminants without MCLs. Institutional controls shall be maintained until COC concentrations fall below MCLs or 1.0E-04 to 1.0E-06 risk-based concentrations for contaminants without MCLs.

Changes to the final RAOs were made in the 2001 ROD Amendment. The Agencies agreed to the following final RAOs for the entire contaminant plume:

- $\quad$ Restore the contaminated aquifer groundwater by 2095 (100 years from the signature of the 1995 ROD) by reducing all COCs to below MCLs and a $1 \times 10^{-4}$ total cumulative carcinogenic risk-based level for future residential groundwater use and, for non-carcinogens, until the cumulative hazard index is less than 1.

- $\quad$ For above-ground treatment processes in which treated effluent will be reinjected into the aquifer, reduce concentrations of VOCs to below MCLs and a $1 \times 10^{-5}$ total risk-based level.

- Implement institutional controls to protect current and future users from health risk associated with ingestion or inhalation of or dermal contact with contaminants in concentrations greater than the MCLs, or greater than a $1 \times 10^{-4}$ cumulative carcinogenic risk-based concentration or a cumulative hazard index of greater than 1 , whichever is more restrictive. The institutional controls shall be maintained until concentrations of all COCs are below MCLs, and until the cumulative carcinogenic risk-based level is less than $1 \times 10^{-4}$, and, for non-carcinogens, until the cumulative 
hazard index is less than 1 . Institutional controls shall include access restrictions and warning signs.

\subsection{Remedy Monitoring}

Remedy monitoring will be implemented to ensure that the selected remedy will meet all RAOs as identified above. The monitoring strategy for the medial zone is outlined in Table 2-1. This monitoring is divided into compliance and performance monitoring. The performance and compliance sampling results will be used to support Agency 5-year reviews for evaluation of remedy performance.

Although the monitoring activities outlined in this RAWP are specific to the medial zone, groundwater sampling activities in support of other OU 1-07B remedial components coincide with those for the NPTF. Table 2-2 identifies all the compliance and performance monitoring activities that will be performed in association with the three monitoring zones.

\subsubsection{Performance Monitoring}

The performance monitoring strategy is divided into two components:

1. Upgradient source control monitoring-To provide early warning of groundwater anomalies that could possibly impact the performance of the NPTF.

2. Plume Capture Monitoring - To assure that a sufficient portion of the plume is being captured and treated so that medial zone cleanup can be completed by 2095 .

The above strategies are discussed in the following sections.

2.1.1.1 Upgradient Source Control Monitoring. In order to provide early warning of groundwater anomalies that could impact the NPTF's ability to meet established discharge criteria, the project team will review VOC and radionuclide concentration data collected at TAN-28, TAN-29 and TAN-30A. If the data show that there are increasing concentration trends moving downgradient towards the NPTF, then an evaluation will be performed to determine and implement operational controls within the NPTF to ensure that the treated water will meet the NPTF operational requirements. As stated in the ROD Amendment (DOE-ID 2001b), the contingency remedy would involve operation of the existing Air Stripper Treatment Unit (ASTU) to extract groundwater from a well upgradient of the NPTF, treat the contaminated water through air stripping to remove VOCs, and reinject the treated water in an injection well located upgradient near the hot spot to facilitate sorption of radionuclides onto subsurface soil and rock. Wells TAN-28, -29 , and $-30 \mathrm{~A}$ are routinely monitored as part of ongoing operations for the ISB and MNA remedies; therefore, data gathering for the NPTF performance monitoring strategy will simply require integration and coordination of the monitoring frequency with the ISB and the MNA monitoring programs. If more frequent samples from these wells are needed for the evaluation, then additional samples will be added to the NPTF SAP.

2.1.1.2 Plume Capture Monitoring. The NPTF extraction/injection system was designed to capture $150 \%$ of the 1997 historical medial zone width. That design capture width is approximately $225 \mathrm{ft}$ on either side of the longitudinal axis of the 1997 medial zone, as measured perpendicular to the ambient direction of groundwater flow (i.e., $225 \mathrm{ft}$ north-northeast [NNE] and south-southwest [SSW] of the axis). Because TAN-40 is located very near the longitudinal axis of the plume, the 450 - $\mathrm{ft}$ capture width (225 ft both NNE and SSW of the center line) can also be applied at TAN-40 in cases where TAN-40 is the only well being pumped. 
Table 2-1. Operable Unit 1-07B groundwater remediation remedy monitoring crosswalk table.

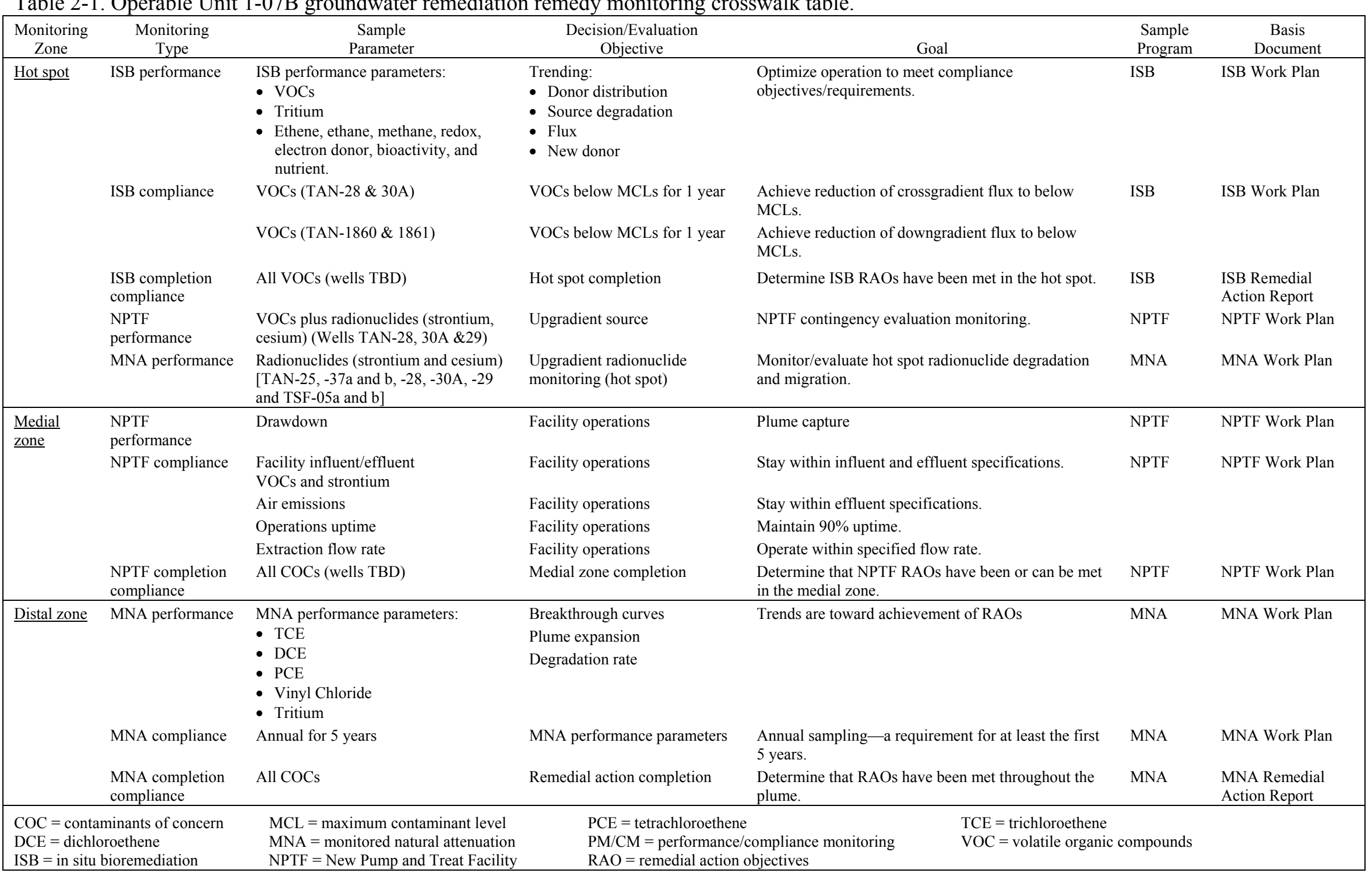


Table 2-2. New Pump and Treat Facility performance monitoring / compliance monitoring criterion.

\begin{tabular}{|c|c|c|c|c|}
\hline \multicolumn{5}{|c|}{ Monitoring Summary } \\
\hline Remedy Phase & Performance Monitoring & Compliance Monitoring & $\begin{array}{c}\text { Medial Zone Completion } \\
\text { Criteria } \\
\end{array}$ & Notes \\
\hline $\begin{array}{l}\text { Long-term operations } \\
\text { Goal: To capture and } \\
\text { treat groundwater from } \\
\text { the medial zone for a } \\
\text { sufficient period of time } \\
\text { to restore the aquifer to } \\
\text { COC concentrations less } \\
\text { than MCLs, a hazard } \\
\text { index less than } 1 \text {, and } \\
\text { cumulative carcinogenic } \\
\text { risk less than } 1 \times 10^{-4} \text { by } \\
2095 \text {. }\end{array}$ & $\begin{array}{l}\text { Upgradient source control monitoring: } \\
\text { Evaluate ISB monitoring data, including } \\
\text { data from TAN-29, to provide early warning } \\
\text { of groundwater anomalies that may impact } \\
\text { the performance of the NPTF. } \\
\text { Plume capture monitoring: } \\
\text { Monitor draw down at least once every } \\
6 \text { months to verify capture of groundwater } \\
\text { to a distance greater than } 225 \mathrm{ft} \text { from } \\
\text { TAN-40, in the direction perpendicular to } \\
\text { the direction of groundwater flow in the } \\
\text { medial zone (i.e., } 225 \mathrm{ft} \text { NNE and SSW of } \\
\text { TAN-40). }\end{array}$ & $\begin{array}{l}\text { Facility operations: } \\
\text { Facility compliance will be } \\
\text { monitored throughout the } \\
\text { operating life of the NPTF and } \\
\text { will include: } \\
\text { Influent concentrations: Monitor } \\
\text { water influent at SP-1. } \\
\text { Air emissions: Shall remain below } \\
\text { 0.18 lb/hr TCE. Air effluent will } \\
\text { be monitored at SP-3 and SP-4. } \\
\text { Effluent concentrations: VOC } \\
\text { concentration shall remain below } \\
\text { MCLs and a } 1 \times 10^{-5} \text { total } \\
\text { risk-based level. Water effluent } \\
\text { will be sampled at SP-2. } \\
\text { Operational Uptime: } \\
>90 \% \\
\text { Extraction Flow Rate: } \\
120-250 \text { gpm. } \\
\text { Remedy compliance: } \\
\text { After the hot spot downgradient } \\
\text { and crossgradient flux has been } \\
\text { cut off and when all COC influent } \\
\text { concentrations into the NPTF are } \\
\text { below MCL's or have reached a } \\
\text { long-term steady state condition, } \\
\text { place the NPTF in standby and } \\
\text { monitor all medial zone wells } \\
\text { annually for } 5 \text { years } \\
\text { (semi-annually for first year) to } \\
\text { evaluate and determine if the } \\
\text { RAO's can be achieved in the } \\
\text { medial zone by } 2095 \text {, without } \\
\text { further operation of the NPTF. }\end{array}$ & $\begin{array}{l}\text { Long-term operations will } \\
\text { consist of a time period in which } \\
\text { the NPTF reduces } \\
\text { concentrations to RAOs, or until } \\
\text { concentrations can be reduced to } \\
\text { a level that will meet RAOs by } \\
\text { using MNA by } 2095 \text {. }\end{array}$ & $\begin{array}{l}\text { Long-Term Operations began } \\
\text { October } 1,2001 \text {. } \\
\text { Periodic performance and } \\
\text { compliance monitoring } \\
\text { reports will be submitted to } \\
\text { the agencies no less than } \\
\text { every } 5 \text { years. } \\
\text { Facility operations reports } \\
\text { will be submitted to the } \\
\text { agencies no less frequently } \\
\text { than semi-annually. } \\
\text { Draw down tests will be } \\
\text { performed every } 6 \text { months. } \\
\text { The transducer array will be } \\
\text { set to record water levels at } \\
1 \text {-minute intervals, from } \\
2 \text { hours before shutdown to a } \\
\text { minimum of } 2 \text { hours after } \\
\text { startup. }\end{array}$ \\
\hline
\end{tabular}


In order to identify antecedent trends and drawdown water levels at the observation wells, water levels will be measured (using electronic transducers and data loggers) prior to and after the startup of the NPTF extraction well pump. Based on preliminary testing, this data collection interval has proven useful for drawdown determinations. Water level measurements will be taken at least every 6 months. The wells used for drawdown measurements are identified in Table 2-3.

Table 2-3. New Pump and Treat Facility drawdown measurement wells.

\begin{tabular}{cll}
\hline Well \# & Direction & \multicolumn{1}{c}{ Comments } \\
\hline TAN-19 & Transverse & \\
TAN-32 & Transverse & $\begin{array}{l}\text { Capture zone achieved if drawdown is measured while pumping at } \\
\text { TAN-40 }\end{array}$ \\
TAN-33 & Transverse & \\
TAN-34 & Transverse & \\
TAN-36 & Transverse & Capture zone achieved if drawdown is measured while pumping at \\
& TAN-38 & \\
TAN-41 & Longitudinal & \\
TAN-42 & Longitudinal & \\
TAN-43 & Longitudinal & \\
TAN-44 & Longitudinal & \\
TAN-45 & Transverse & \\
\hline
\end{tabular}

\subsubsection{Compliance Monitoring}

The compliance monitoring strategy is divided into two components:

1. Facility operation compliance-To assure facility operation meets design specifications and ARAR.

2. Remedy compliance-To gauge compliance with RAOs.

2.1.2.1 Facility Operation Compliance Monitoring. Facility operation compliance is conducted during facility operations to provide data with which to evaluate system performance relative to design specifications. This monitoring is conducted from facility start-up to the end of long-term operations. It leads to periodic decisions regarding whether the facility is operating as expected and whether the remedy is trending toward meeting RAOs. These data are also reported periodically in routine operations reports. Once the monitoring data indicates that RAOs may have been achieved, the final component of the compliance monitoring strategy is implemented.

2.1.2.2 Remedy Compliance Monitoring. Remedy compliance is conducted once facility operations compliance monitoring data indicate that RAOs may have been achieved. This component of the compliance monitoring strategy is designed to provide data for agency review to determine that the remedy component has achieved RAOs within the medial zone. 


\subsection{Remedy Performance Review and Closure}

The 1-07B ROD (DOE-ID 1995) and the ROD Amendment (DOE-ID 2001b) require the Agencies to evaluate the effectiveness of the remedy in accordance with the standard CERCLA 5-year review process. Based on the evaluations performed during the 5-year reviews, the Agencies will decide to continue, modify, or discontinue the medial zone remedial action. The timing and approach for conducting 5-year reviews is addressed in the NPTF O\&M plan (DOE-ID 2003a).

The planning and costing assumptions for the medial zone used in the $1995 \mathrm{ROD}$ and the RD/RA SOW (DOE-ID 1995, 1997b), assume an active remedial action time period of 30 years. Active remedial actions refer to remediation activities that involve other-than-natural processes (natural attenuation) and require O\&M of a remedial action treatment system. The 5-year review process will ultimately provide for the completion of O\&M activities with respect to the active remediation time period. At the completion of O\&M activities, an O\&M report will be prepared to support an agency decision that the active remedial action has been successful in supporting the RAOs for the medial zone. The O\&M report also will specify any additional monitoring that will be performed under the MNA monitoring plan to ensure that the RAOs are maintained and/or achieved at the end of the 100-year remedial action time frame established in the ROD. The approach and requirements for the O\&M report are addressed in the NPTF O\&M Plan (DOE-ID 2003a). 


\section{REGULATORY COMPLIANCE}

The OU 1-07B 1995 ROD and the 2001 ROD Amendment identify the medial zone remedy as meeting the statutory requirements of Section 121 of CERCLA, as amended by the Superfund Amendments and Reauthorization Act, and to the extent practicable, the NCP. These statutory requirements are met through the remedy being protective of human health and the environment, and through remedy compliance with ARARs). Compliance with ARARs is addressed in the following sections.

\subsection{Compliance with Applicable or Relevant and Appropriate Requirements}

A detailed list of ARARs for the selected alternative is shown in Table 3-1. The table also identifies the documents that provide the specific ARAR implementation. The ARAR implementation strategy for the OU 1-07B Project is identified in Appendix A.

\subsection{Environmental Compliance}

The medial zone remediation activities comply with the substantive requirements of the National Environmental Policy Act (NEPA) through compliance with an environmental checklist specific to the NPTF operations. The environmental checklist provides the process review required to ensure compliance with environmental regulations.

\subsection{Human Health and Safety}

The medial zone remedial activities are performed in accordance with the requirements of the Occupational Safety and Health Administration (OSHA) Standards 29 CFR 1910.120 and 1926.65, "Hazardous Waste Operations and Emergency Response." These requirements are implemented in accordance with the OU 1-07B HASP (INEEL 2002c).

\subsection{U.S. Department of Energy Orders}

There are numerous U.S. Department of Energy (DOE) directives in the form of orders, manuals, notices, and standards that must be complied during the performance of work at the Idaho National Engineering and Environmental Laboratory (INEEL). These directives govern all aspects of work at the INEEL and are typically implemented through Management Control Procedures, Technical Procedures, Plans, and other Site documents. 
Table 3-1. Summary of applicable or relevant and appropriate requirements for remedial action.

\begin{tabular}{|c|c|c|c|c|c|c|c|c|}
\hline \multirow[b]{2}{*}{ Requirements } & \multicolumn{8}{|c|}{ ARAR Applicability by Location } \\
\hline & Citation $^{\mathrm{a}}$ & RAWP & $\begin{array}{c}\text { Remedial } \\
\text { Design }\end{array}$ & O\&M Plan & WMP & SAP & IDP & HASP \\
\hline \multicolumn{9}{|l|}{ Clean Air Act and Idaho Air Regulations } \\
\hline Idaho Air Pollutants, noncarcinogens & IDAPA 16.01.01.585 & - & $\mathrm{X}$ & - & - & - & - & - \\
\hline Idaho Air Pollutants, carcinogens & IDAPA 16.01 .01 .586 & - & $\mathrm{X}$ & - & - & - & - & - \\
\hline NESHAPs $-<10 \mathrm{mrem} / \mathrm{yr}$ & 40 CFR 61.92 & - & $\mathrm{X}$ & $\mathrm{X}$ & - & - & - & - \\
\hline NESHAPs - monitoring & 40 CFR 61.93 & - & $\mathrm{X}$ & $\mathrm{X}$ & - & - & - & - \\
\hline ID Fugitive Dust & IDAPA 16.01 .01 .650 and .651 & - & $\mathrm{X}$ & $\mathrm{X}$ & - & - & - & $\mathrm{X}$ \\
\hline \multicolumn{9}{|l|}{ RCRA and HWMA } \\
\hline Generator Standards & IDAPA 16.01.05.006 & & & & & & & \\
\hline Hazardous Waste Determination & 40 CFR 262.11 & - & - & - & $\mathrm{X}$ & - & - & - \\
\hline General Facility Standards & IDAPA 16.01.05.008 & & & & & & & \\
\hline General Waste Analysis & 40 CFR 264.13 & - & - & - & $\mathrm{X}$ & - & - & - \\
\hline Location Standards & 40 CFR 264.18 (a) and (b) & $\mathrm{X}$ & $\mathrm{X}$ & $\mathrm{X}$ & - & - & - & - \\
\hline Preparedness and Prevention & 40 CFR 264.31-.37 & - & $\mathrm{X}$ & $\mathrm{X}$ & $\mathrm{X}$ & - & - & $\mathrm{X}$ \\
\hline Closure Performance Standard & 40 CFR 264.111 & $\mathrm{X}$ & $\mathrm{X}$ & $\mathrm{X}$ & - & - & - & $\mathrm{X}$ \\
\hline Disposal/Decontamination & 40 CFR 264.114 & $\mathrm{X}$ & $\mathrm{X}$ & $\mathrm{X}$ & - & - & - & $\mathrm{X}$ \\
\hline Use/Management of Containers & 40 CFR 264 Subpart I & - & $\mathrm{X}$ & $\mathrm{X}$ & $\mathrm{X}$ & - & - & - \\
\hline Tank Systems & 40 CFR 264 Subpart J & - & $\mathrm{X}$ & $\mathrm{X}$ & - & - & - & - \\
\hline Land Disposal Restrictions & IDAPA 16.01.05.011 & - & - & - & - & - & - & - \\
\hline RCRA & Section 3020 & - & $\mathrm{X}$ & - & - & - & - & - \\
\hline \multicolumn{9}{|l|}{ Underground Injection Control } \\
\hline $\begin{array}{l}\text { Idaho Rules for the Construction and } \\
\text { Use of Injection Wells }\end{array}$ & IDAPA 37.03 .03 & - & $\mathrm{X}$ & - & - & - & - & - \\
\hline \multicolumn{9}{|l|}{ ID Public Drinking Water } \\
\hline MCLs (numerical standards only) & IDAPA 16.01.08.050.02 and .05 & - & - & $\mathrm{X}$ & - & $\mathrm{X}$ & - & - \\
\hline $\begin{array}{l}\text { Secondary MCLs (numerical } \\
\text { standards only) }\end{array}$ & IDAPA 16.01.08.400.03 & - & - & $\mathrm{X}$ & - & - & - & - \\
\hline \multicolumn{9}{|l|}{ National Historic Preservation Act } \\
\hline Assessing information needs & 36 CFR 800.4(a)(1)(i),(iii)(a)(2) & $\mathrm{X}$ & $\mathrm{X}$ & $\mathrm{X}$ & - & - & - & - \\
\hline Locating Historic Properties & 36 CFR 800.4(b) & - & $\mathrm{X}$ & - & - & - & - & - \\
\hline
\end{tabular}


Table 3-1. (continued).

ARAR Applicability by Location

\begin{tabular}{|c|c|c|c|c|c|c|c|c|}
\hline \multirow[b]{2}{*}{ Requirements } & \multicolumn{8}{|c|}{ ARAR Applicability by Location } \\
\hline & Citation $^{\mathrm{a}}$ & RAWP & $\begin{array}{c}\text { Remedial } \\
\text { Design }\end{array}$ & O\&M Plan & WMP & SAP & IDP & HASP \\
\hline \multicolumn{9}{|l|}{ To Be Considered } \\
\hline $\begin{array}{l}\text { Radiation Protection of the Public and } \\
\text { the Environment }\end{array}$ & DOE Order 5400.5 & - & $\mathrm{X}$ & - & - & - & - & $\mathrm{X}$ \\
\hline \multicolumn{9}{|c|}{ a. Citation of the Idaho Administrative Procedure Act incorporated by reference to the federal hazardous waste regulations as listed. } \\
\hline $\begin{array}{l}\text { CFR = Code of Federal Regulations } \\
\text { HWMA = Hazardous Waste Management Act } \\
\text { HASP = Health and Safety Plan } \\
\text { IDAPA = Idaho Administrative Procedures Act } \\
\text { IDP = Interim Decontamination Plan } \\
\text { MCL = maximum contaminant level } \\
\text { NESHAPS = National Emissions Standards for Ha } \\
\text { RAWP = Remedial Action Work Plan } \\
\text { RCRA = Resource Conservation and Recovery Ac } \\
\text { SAP = Sampling and Analysis Plan } \\
\text { WMP = Waste Management Plan }\end{array}$ & zardous Air Pollutants & & & & & & & \\
\hline
\end{tabular}




\section{REMEDIAL ACTION}

This section addresses the procurement and construction of the NPTF, along with the administrative requirements for SO testing, prefinal inspection, initial operation, shakedown, and final inspection, which lead up to the NPTF being deemed operational and functional in the NPTF Remedial Action Report.

The activities discussed in this section were completed prior to Revision 1 of this document. Therefore, the text within this section has been revised to reflect how the activities were actually performed.

\subsection{Facility Procurement and Construction}

This section identifies the construction activities, project and construction management plans, procurement and subcontracting plans, quality assurance, and construction completion and inspection plans used to prepare the NPTF for the start of remedial activities. Figure 4-1 is a logic diagram that was used by the project to proceed from construction completion to preparing a remedial action report, and then finally to determine that the remedy was operational and functional. This section also identifies the general method of implementation of these activities. Particular attention is focused on unique or special techniques used to accomplish these activities.

\subsubsection{Project Management and Construction Management}

The DOE-ID project remediation manager is responsible for notifying the EPA and DEQ of project activities and to serve as the single interface point for all routine contact between the Agencies and the management and operating (M\&O) Contractor.

The $\mathrm{M} \& \mathrm{O}$ Contractor is responsible for implementation of the remedial action. This includes design, field activities such as groundwater monitoring, facility construction, waste management, health and safety, quality assurance, landlord services, and other necessary tasks for completion of the remedial action.

An organizational chart and position description is provided in the project HASP (INEEL 2002c).

\subsubsection{Procurement and Subcontracting}

The work involved in this remedial action is primarily focused on installing the facilities and ancillary components associated with the NPTF long-term operations. The NPTF construction was accomplished by subcontracting the work. A fixed-price contract was awarded to the lowest qualified bidder for the construction activities. The request for proposal specified (among other things) the period of performance, which corresponded with the overall project schedule.

\subsubsection{Construction Activities}

This section provides a task description of the facility construction activities, which include subcontract work, and site-worker accomplished work. 


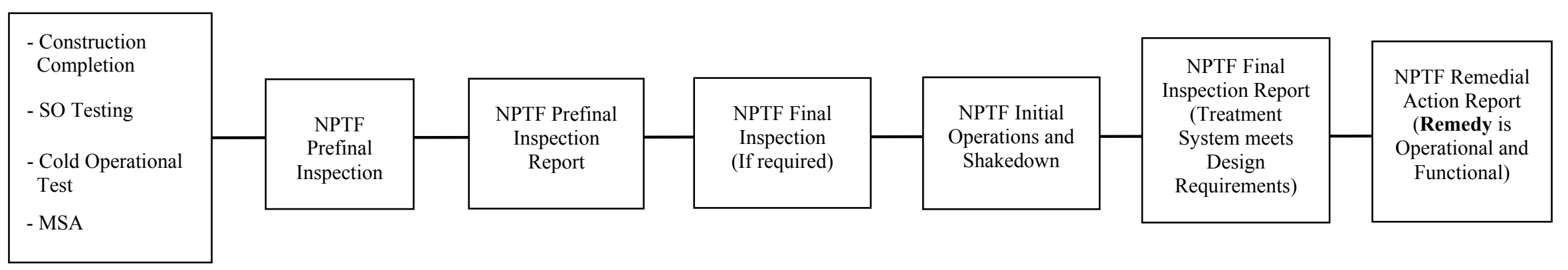

Figure 4-1. Agency remedial action acceptance logic diagram. 
4.1.3.1 Premobilization. This time period was used to prepare the Subcontractor, site workers, and support personnel for the facility construction. This time frame included submittal, review, and approval of vendor data for near-term construction activities and long-lead items, submittal by the Subcontractor of work plans, bonds, insurance certifications, as well as providing other documentation certifying compliance with training, medical, and quality requirements.

This period was used by the Contractor to perform a final assessment of their readiness to proceed with construction. These activities consisted of ensuring that the necessary permits had been acquired, personnel were available and trained, and that all the necessary site and regulatory notifications had been made.

4.1.3.2 Mobilization. This time period was used by the Contractor and Subcontractor to prepare for construction activities. This work included the institution of required administrative and engineering controls including the following:

- Health and safety controls

- $\quad$ Fences, signs, and postings

- Identification and demarcation of the contamination and decontamination zones, lay-down, and staging areas

- $\quad$ Delivery and storage of construction materials and equipment

- $\quad$ Set-up of the subcontractor's site offices.

4.1.3.3 New Pump and Treat Facility Construction. The construction of this facility was composed of three primary components: (1) extraction and reinjection components, (2) process system enclosure, and (3) process system. A description of the activities involved with the construction of these components follows below.

4.1.3.3.1 Extraction and Reinjection Components-The extraction and reinjection components consist of the influent and effluent piping and appurtenances, which extend from the extraction well heads to the process system, and from the process system to the reinjection well. This work included the following:

- $\quad$ Extraction Wells: Three extraction wells were constructed, and are used in support of this facility (Wells TAN-38, -39, and -40). These wells are completed as open hole wells with no additional down hole well completion planned for these wells.

Each extraction well is equipped with an extraction pump and associated piping to bring the water to the surface and into the NPTF. During installation, the potential existed that this work would involve decontamination of equipment that came in contact with F001-listed groundwater. The OU 1-07B Interim Decontamination Plan (INEEL 2002b) and the Waste Management Plan (WMP) (INEEL 2002a) were followed to handle any residue that was produced as a result of these activities.

- $\quad$ Reinjection Well: A reinjection well (TAN-53A) was installed downgradient from the extraction wells location. This well is located approximately $170 \mathrm{~m}(558 \mathrm{ft})$ southeast of the NPTF. This well was completed with casing to the water table approximately $64 \mathrm{~m}(210 \mathrm{ft})$ below land surface and 
as an open hole to the Q-R interbed. The reinjection well is equipped with an effluent line downhole. See the remedial design for more information on this well and its location.

- Installation of power and control wiring from the process system to the well heads, and installation of valves and associated flow-control devices.

- Well Head Housing: Each extraction well is equipped with a well head housing enclosure. This structure is constructed of metal components, insulated and heated, and provided with electrical service. This structure is removable for ease of maintenance of the well and well-head components and appurtenances.

This work included installation of a concrete foundation, including the requisite excavation, compaction, formwork, and finishing. The metal structure was constructed of lightweight metal structural components, wall and roof panels, and did not require extraordinary hoisting or construction techniques. The electrical service for the heating, lighting, and control features are powered and routed from the process facility building; they are considered minimal in nature.

- $\quad$ Extraction and Reinjection Influent and Effluent Piping: The piping manifold system for the extraction system involved construction of a large amount of double-walled piping in order to meet the 40 CFR 264, Subpart J secondary-containment requirements for tank systems processing hazardous waste. The reinjection piping does not require double-wall pipe.

There were no extraordinary construction techniques involved with the construction of this piping. All process piping was installed above ground.

4.1.3.3.2 Process System Enclosure-The process system enclosure is the building that houses the water treatment system. The following work describes the foundation, building, heating, ventilation, and the building's electrical system:

- This work included installation of a concrete foundation and interior floor, including the requisite excavation, compaction, formwork, and finishing. The concrete floor within the enclosure provides secondary containment for the process equipment. Features include curbing, sloped floors, drain trench, and sump. Areas designated as a secondary containment were coated with an impermeable coating to prevent leaching of water and contaminants into the concrete floor.

- $\quad$ The building was a pre-engineered building constructed of structural steel, with metal walls and roof.

- Interior utilities include heating and ventilation, potable water, and electrical light fixtures and outlets. An electrical room was installed that provides the service panels for the building services, process system, and outlying well heads.

4.1.3.3.3 Process System-The process system consists of equipment, piping, pumps, tanks, and controls necessary to support operation of two parallel air stripper trains. Details regarding the system include the following:

- The process system materials and equipment are off-the-shelf items. The air stripper units were sized and specified per the specific requirements and concentration of VOCs present within the medial zone. 
- The surge tank, air strippers, flow control valves and level indicators are all controlled within the electrical control room using the system control panel. A programmable logic controller is used to monitor system water levels and to adjust system flow rates as needed to maintain the required process limits.

4.1.3.4 Construction Completion and Closeout. Upon completion of the construction, the Subcontractor and Contractor performed a facility walkdown and developed a punch list to record deficient items. The walkdown also included a cold test of individual components to determine that they operated in accordance with the applicable specifications.

4.1.3.5 Demobilization. After the construction activities and inspections were satisfactorily completed and all equipment was operating properly, the Subcontractor demobilized from the construction site.

\subsection{Startup and Operational Testing}

After construction was complete, system operation (SO) testing was performed on all systems components to ensure that the equipment was properly installed and operated in accordance with the design specifications. The SO testing was followed by a treatment system cold test to demonstrate proper operation of the total treatment system. The SO was performed in accordance with written startup and test procedures. For the operational cold test, all O\&M procedures required for treatment system operations were complete. The required O\&M procedures are identified in the NPTF O\&M Plan (DOE-ID 2003a).

Prior to the operational cold test, the project conducted a management self-assessment of the facility and of the facility's operational readiness. This included a review of procedures, training, and other items necessary to safely operate the system.

\subsection{Prefinal Inspection Activities}

The prefinal inspection report provides a means to document the prefinal inspection performed by the DOE-ID, EPA, and DEQ project managers or their designees, at completion of construction activities for long-term remedial actions, or at completion of remediation for short-term remedial actions.

\subsubsection{Prefinal Inspection}

The prefinal inspection of the NPTF was conducted by the agency project managers or their designees, prior to initial operations and shakedown of the treatment system. A prefinal inspection checklist was prepared prior to conducting the inspection and was agreed to by the Agencies prior to performing the inspection. An inspection was then conducted with all open items identified and recorded on the checklist. At the end of the inspection, the Agencies determined which open items required closure prior to the start of processing contaminated water.

\subsubsection{Prefinal Inspection Report}

A prefinal inspection report was prepared to document the results of the prefinal inspection. The report identified the open items from the inspection, the agreed-upon action for closing the open items, and the scheduled closure date for each open item. The prefinal inspection report was prepared as a secondary document for review by the Agencies. The prefinal inspection report included the following information:

- $\quad$ Completed prefinal inspection checklist 
- $\quad$ Identification of open items

- Actions and schedule for closure of open items

- $\quad$ SO testing and operational cold test results

- $\quad$ Planned date for final inspection.

\subsection{Final Inspection Activities}

A final inspection was performed by the agencies to review the closure of the open items documented during the prefinal inspection.

\subsubsection{Final Inspection}

The final inspection focused on closure verification of the prefinal inspection open items and satisfactory completion of the shakedown period.

\subsubsection{Final Inspection Report}

As defined in the RD/RA SOW (DOE-ID 1997b), a final inspection report was prepared for the NPTF. The final inspection report addressed the following information:

- $\quad$ Results of the final inspection

- Evaluation of the effectiveness in meeting treatment system performance requirements based on the results of the shakedown period

- $\quad$ Resolution of outstanding items from the prefinal inspection report

- $\quad$ Explanation of any changes from the remedial design and RAWP

- $\quad$ O\&M plan update.

\subsection{Initial Operations and Shakedown Period}

Initial treatment system operations with contaminated groundwater began after satisfactory closure of prefinal inspection open items. The initial operations included a shakedown period to verify that the NPTF met system performance requirements. The operational shakedown period was used to carefully monitor system performance in order to ensure that (a) the system was operating in accordance with the approved specifications, (b) is operational and functional, and (c) is compliant with all applicable ARARs.

Further operational shakedown requirements are detailed in the NPTF O\&M Plan (DOE-ID 2003a). 


\subsection{Remedial Action Report}

As specified in the RD/RA SOW (DOE-ID 1997b), a remedial action report was prepared for the NPTF. The remedial action report is a primary document with a draft, draft final, and final submittals. The milestone date for this document is established in Section 11.

The remedial action report addressed the following information:

- $\quad$ Summary of remedial action components as defined in this RAWP

- Explanation of changes to the remedial design and RAWP

- $\quad$ Summary of the results from operational testing, the shakedown period, and the final inspections

- $\quad$ Evaluation of the effectiveness in meeting treatment system performance requirements

- Documentation of closure of any open items from the final inspection reports

- Summary of data collected during the remedial action that support a determination that the remedy is operational and functional

- Certification that the remedy is operational and functional

- Identification of needed changes to the O\&M plan. 


\section{OPERATIONS AND MAINTENANCE}

The routine O\&M activities and procedures for the medial zone remedial action component are covered in the NPTF O\&M Plan (DOE-ID 2003a). The NPTF O\&M Plan identifies the approach and requirements for the O\&M activities applicable to the medial zone portion of the OU 1-07B final remedial action. Additional remedy components for the hot spot and the distal zone of the plume will have separate RD/RA and operational documents. The scope of the O\&M plan includes NPTF O\&M, groundwater monitoring, remedy 5-year reviews, and the final O\&M report. The following are brief descriptions of the sections from the O\&M plan:

- $\quad$ Operations and Maintenance

This section discusses and covers the routine O\&M of the NPTF system. This includes identification and discussion of operating parameters, O\&M procedures, inspection requirements, and waste management requirements. The operating parameters discussed are operational uptime requirements, upset conditions, and unplanned maintenance. The procedures that are outlined pertain to O\&M of the NPTF treatment system. The inspection requirements discussed are those that are driven by regulations or considered as good management practice.

\section{- $\quad$ Remedy Compliance and Performance Monitoring}

This section discusses the implementation of the compliance and performance monitoring requirements. Compliance monitoring will be used to ensure the facility is operating in compliance with treated water effluent and air emission ARARs. Performance monitoring will be used to provide a periodic assessment of the treatment systems' ability to remediate the medial portion of the plume. Groundwater monitoring will be used to provide a periodic assessment of the overall plume remediation activities.

- $\quad$ Remedy Performance Review and Closure

This section discusses and covers 5-year reviews and the O\&M report. The 5-year review section identifies the methods and criteria for measuring performance of the remedy during the remediation time frame. The purpose of the O\&M report will be to provide information that will support an Agency decision that the active remedial action has been successful in supporting the medial zone RAOs.

- Institutional Controls

This section discusses and covers planned administrative and engineering controls to protect current and future users from health risks associated with groundwater contamination.

- Decontamination and Decommissioning

This section addresses the requirements for interim decontamination and final decontamination and decommissioning (D\&D). 
- $\quad$ Reports

This section provides a summary of the reporting requirements applicable to the medial zone operations. Reports that are to be provided include:

- $\quad$ National Emission Standards for hazardous air pollutants

- $\quad$ Annual performance report

- $\quad$ Five-year review reports

- $\quad$ O\&M report.

- $\quad$ Safety, Health, and Quality

This section identifies where and how safety, health, and quality requirements are covered for NPTF operations. 


\section{DECONTAMINATION AND DECOMMISSIONING}

Decontamination is a process whereby contaminants that have accumulated on or in equipment, tools, or treatment systems, are removed or neutralized such that they no longer present a hazard to human health or the environment. Decontamination efforts associated with OU 1-07B have been grouped into two activities: those that are involved with day-to-day operations, and those that are associated with the final shut down and decommissioning of the NPTF.

\subsection{Interim Decontamination}

Detailed procedures for decontamination of equipment and other miscellaneous items may be found in the Interim Decontamination Plan for OU 1-07B (INEEL 2002b).

Decontamination of the tanks, containers, and equipment used for the remedial actions associated with OU 1-07B involves removal and disposal of wastes present in the containers, and decontamination of the interiors of tanks, containers, and associated ancillary equipment that were in contact with waste, as necessary. Decontamination consists of rinsing the item to be decontaminated with water to meet the performance criteria in the interim decontamination plan. Spent decontamination water and other liquid waste streams generated during the decontamination process will be assessed for compatibility with the NPTF. Those streams that are compatible will be transferred to the NPTF for processing and disposal. Those waste streams that are not compatible with NPTF operations will be sampled and analyzed for characterization in accordance with the WMP (INEEL 2002a).

\subsection{Final Decontamination and Decommissioning}

Final D\&D of NPTF will be addressed after the Agencies determine that the active remediation is complete and/or that the treatment system is no longer required. The D\&D requirements will be addressed in a future D\&D plan. The D\&D plan will direct that all tanks, containers, piping, and equipment will be flushed with clean water to remove as much contamination as possible. The system will then be dismantled and made ready for decontamination as directed by management. Components that can be decontaminated will be released for use in other systems or disposed of as industrial waste. The site will be returned to its preoperation condition to the extent feasible considering cost and intended future use.

The wells that are used in conjunction with the NPTF will continue to be used for monitoring the aquifer within the medial zone. If a well is no longer needed, it will be abandoned in accordance with INEEL and State of Idaho well-abandonment procedures.

The OU 1-07B CERCLA waste storage units (CWSU) will remain in place to accommodate project waste storage as needed. The project waste stored within the CWSUs will be processed and disposed of as addressed in the WMP. 
6-2 


\section{WASTE MANAGEMENT}

All wastes generated during medial zone remedial action will be managed in accordance with applicable waste management requirements including those contained in the Waste Certification Plan for the Environmental Restoration Program (INEEL 1997a) and the Idaho National Engineering and Environmental Laboratory Waste Acceptance Criteria (DOE-ID 2003c). All waste management activities will be conducted in accordance with the applicable substantive requirements specified in the project ARARs. The specific requirements for waste identification, characterization, segregation, packaging, labeling, storage, and inspection applicable to OU 1-07B are identified in the Phase C Waste Management Plan (INEEL 2002a).

Specific waste management regulatory issues that are applicable to OU 1-07B are summarized in the following sections.

\subsection{Resource Conservation and Recovery Act Listed Waste}

\subsubsection{Listed Waste Determination}

The TSF-05 injection well was drilled in 1953 to a depth of $93 \mathrm{~m} \mathrm{(310} \mathrm{ft)} \mathrm{to} \mathrm{dispose} \mathrm{of} \mathrm{liquid}$ effluent generated from the Aircraft Nuclear Propulsion (ANP) project. Discharges to the well include organic sludges, treated sanitary sewage, process wastewater, and low-level radioactive waste streams. The principal VOC discharged was TCE. Estimates of the volume of TCE discharged to the well range from 1,325 to 97,161 L (350 to 25,670 gal). Previous evaluations of the solvents used at TAN concluded that the waste discharged to the injection well was not an RCRA-listed hazardous waste because the organic chemicals in the waste were not used as solvents or for degreasing, and because actual usage practices are not known (DOE-ID 1995).

In April 1997, based on new information, it was determined that an RCRA-listed solvent, TCE, was disposed of at the TAN Facility via the TSF-21 valve pit. Since the valve pit was connected to the TSF-05 injection well, the injection well and associated groundwater contamination plume are considered to contain RCRA-listed wastes. The RCRA-listed waste classification, waste code F001, is therefore applicable to the TCE contaminated TAN groundwater and associated waste streams, and the substantive requirements of the ARARs are applicable for the RCRA-listed waste (INEEL 1997b). The listed waste determination was implemented for OU 1-07B for waste that was not previously determined to be characteristic, based on an OU 1-07B Waste Management Compliance Commitments and Schedule dated July 22, 1997, which was concurred with by the agencies per a DOE letter of August 29, 1997. ${ }^{\text {a }}$

\subsubsection{No-Longer-Contained-In Determination}

In accordance with 40 CFR 261.3, "Identification and Listing of Hazardous Waste," environmental media are considered to potentially contain RCRA-listed hazardous wastes, if there was a release to the media that included these wastes. Of the options available to manage wastes containing low to nondetectable concentrations of listed wastes, a no-longer-contained-in determination (NLCID) may be requested for these environmental media, soil, and groundwater. Until a NLCID is made for the OU 1-07B waste streams, that media will be managed as a listed hazardous CERCLA waste in accordance with the WMP (INEEL 2002a). In accordance with the ROD Amendment (DOE-ID 2001b), the NCLID is applicable to the waste stream once the air stripping process is complete, resulting in hazardous constituent concentrations less than MCLs and with a cumulative carcinogenic risk of less than $1 \times 10^{-5}$. The NLCIDs that have been approved are attached to the WMP.

a. Hain, K. E., DOE-ID, Manager of Environmental Restoration Program, to K. L. Falconer, INEEL, Director of Environmental Restoration, August 29, 1997, DOE-ID Letter OPE-ER-129-97. 


\subsection{Toxic Substances and Control Act Regulated Wastes}

In the 1950s, the V-Tanks were installed to store liquid radioactive waste generated at TAN prior to treatment. Liquid wastes were pumped to these tanks from the TSF laboratories and craft shops, hot and warm shops, a radioactive decontamination shop, hot cells, and the Initial Engine Test Facility. In 1968, approximately $227 \mathrm{~L}$ ( $60 \mathrm{gal}$ ) of oil was discovered in Tank V-2, reportedly from a spill of hydraulic oil in the hot cell. This oil was subsequently removed in 1981 and sampled. The analysis of the oil revealed polychlorinated biphenyl (PCBs) (Aroclor 1260) concentration up to $680 \mathrm{mg} / \mathrm{kg}$. ${ }^{\text {b }}$ The PCBs have been identified in all three tanks with maximums of $660 \mathrm{mg} / \mathrm{kg}$ in V-1, $260 \mathrm{mg} / \mathrm{kg}$ in V-2, and $400 \mathrm{mg} / \mathrm{kg}$ in V-3. The V-Tanks have not been used since the early 1980s. Treatment for the liquid radioactive waste, when the V-Tank system was in operation, consisted of processing the liquid waste through the evaporator in TAN-616 (and later the PW-2 system) to concentrate the radioactive waste. The wastewater from the evaporator system was discharged to the warm waste system and then to TSF-05.

Recent sampling events at TSF-05 have shown that the PCB concentration in the sludge at the bottom of the well is $6 \mathrm{mg} / \mathrm{kg}$. Since this is less than the $50 \mathrm{mg} / \mathrm{kg}$ addressed in 40 CFR 761, the waste generated during the remedial actions at OU 1-07B will be managed as not containing PCBs until such time as sampling shows that the sludge in TSF-05 has PCB concentrations of $50 \mathrm{mg} / \mathrm{kg}$.

\subsection{Low-Level Radioactive Waste}

Low-level radioactive waste will be generated during OU 1-07B activities. This waste is the result of radionuclide contamination in the TSF-05 injection well and is primarily associated with the sludge

that is recovered from the TSF-05 well. This radioactive waste also normally contains RCRA F001-listed waste and, therefore, is classified as listed mixed waste.

b. Tellez, Carlos, INEEL, Director of Environmental Affairs, to Dan Duncan, EPA, TSCA Program Manager, September 3, 1997, INEEL Letter CLT-84-97. 


\section{EMERGENCY RESPONSE}

Emergency response is covered by the INEEL Emergency Action/RCRA Contingency Plan Addendum for TAN Facilities (PLN-114), while the Emergency Action section of the OU 1-07B HASP (INEEL 2002c) contains primary emergency response actions for OU 1-07B site personnel, initial responses, task site responsibilities, emergency equipment at the task site, emergency response teams, and notification lists. This section of the HASP supplements the INEEL EA/RCRA contingency plan. Copies of both documents are kept in the OU 1-07B office located in Building TAN 607. A copy of the HASP will also be kept in the NPTF control room.

The INEEL EA/RCRA contingency plan includes emergency response organizations and operational emergency event classes of fires, explosions, radiological releases, nonradiological releases, natural phenomena, loss of power, criticalities, safeguards and security, and external events. Sections 5 through 14 of the INEEL EA/RCRA contingency plan address notifications and communications, consequence assessment, protective actions, medical support, recovery and reentry, public information, emergency facilities, training (also covered in the OU 1-07B HASP), drills and exercises, and program administration. Appendix L4 of the INEEL EA/RCRA contingency plan contains the OU 1-07B Appendix "L." This appendix is specific to the OU 1-07B Project and defines specific measures and criteria used for OU 1-07B activities.

Emergency actions are primarily governed by the OU 1-07B HASP; however, when emergencies result that are beyond the limitations of the HASP, the INEEL EA/RCRA contingency plan will be implemented. Therefore, in the event of an emergency, initial responders shall follow the direction of the HASP unless the resulting emergency is designated as a fire, explosion, or an uncontrolled release to the environment, in which case the INEEL EA/RCRA contingency plan will be implemented. 


\section{QUALITY ASSURANCE PROGRAM}

The RAWP is intended to be used in conjunction with the Quality Assurance Project Plan for WAGs 1, 2, 3, 4, 5, 6, 7, 10 and Inactive Sites (QAPjP) (DOE-ID 2002) and the Environmental Restoration Project Management Plan, PLN-694.

The most important activities associated with the medial zone remedial action, with respect to quality assurance, are the data collection and analysis activities for compliance and performance monitoring. The quality assurance for these activities is described in detail in the NPTF O\&M Plan (DOE-ID 2003a) for compliance monitoring, and in the applicable sampling analysis plans for other groundwater monitoring activities throughout the project. 
9-2 


\section{SAFETY AND HEALTH PROGRAM}

The safety and health requirements for the medial zone remedial action activities include the areas of industrial safety, industrial hygiene, fire protection, radiation safety, and emergency preparedness. Safety and health requirements, in accordance with OSHA Standard 29 CFR 1910.120 and 1926.65 "Hazardous Waste Operations and Emergency Response," are designed and established to provide a safe and healthy work environment. Safety and health requirements are being implemented at the INEEL through the DOE Integrated Safety Management System (ISMS) and the Voluntary Protection Program (VPP). The ISMS and VPP provide for the integration of hazard identification and mitigation into the work control process for construction, operations, and maintenance activities.

Specific health and safety requirements, including hazard identification and mitigation, are addressed in the OU 1-07B HASP (INEEL 2002c). 
10-2 


\section{COST AND SCHEDULE}

This section addresses cost, schedule, and deliverables to Phase $\mathrm{C}$ remedy components and activities. Also included is a cost comparison of the current project baseline and the cost estimate in the OU 1-07B ROD. The current project baseline includes a refined cost estimate for NPTF construction based on the New Pump and Treat Facility Remedial Design (DOE-ID 2000).

\subsection{Record of Decision Cost versus Current Baseline}

Outyear funding availability for $\mathrm{RD} / \mathrm{RA}$ projects is subject to congressional approval of $\mathrm{DOE}$ budgets. The DOE has identified adequate funding in existing budget plans for this project. Table 11-1 contains the project cost estimate from the OU 1-07B ROD and the Fiscal Year-98 baseline estimate. This estimate and the assumptions contained in it may be used for comparison throughout the project. Depending on the outcome of the specified ROD and RD/RA SOW decision points, the actual remediation costs are expected to be within -30 to $+50 \%$ of the ROD cost estimate.

Table 11-1. Operable Unit 1-07B cost summary.

\begin{tabular}{|c|c|c|c|}
\hline Work Package & Description & $\begin{array}{l}\text { ROD Cost } \\
\text { Estimate }^{a} \\
\text { FY-95\$ }\end{array}$ & $\begin{array}{c}\text { Baseline Cost } \\
\text { Estimate }^{\mathrm{a}, \mathrm{b}} \\
\text { FY-98 \$ }\end{array}$ \\
\hline WP-2 & Operation Transition from Phase A to Phase B & 1,357 & 2,490 \\
\hline WP-3 & Sludge Treatment/Disposal & 92 & 10 \\
\hline WP-4 & Pre-ROD Scoping & 450 & 443 \\
\hline WP-5 & Cleanup Technical Administrative Activities & 1,862 & 9,597 \\
\hline WP-7 & Hot Spot Containment/Removal & 3,325 & 4,708 \\
\hline WP-8 & NPTF Extraction Wells & 212 & 1,300 \\
\hline WP-9 & Phase C Remediation Operations & 23,718 & 17,795 \\
\hline WP-10 & Groundwater Monitoring & 3,870 & 5,220 \\
\hline WP-11 & Hydrology and Treatability Studies & 4,828 & 11,010 \\
\hline WP-14 & NPTF Design and Construction & $-^{\mathrm{c}}$ & 2,032 \\
\hline WP-15 & Hot Spot Treatment & $-^{\mathrm{c}}$ & 3,180 \\
\hline \multirow[t]{3}{*}{ WP-16 } & Distal Zone Treatment & $-^{\mathrm{c}}$ & 2,420 \\
\hline & Contingency & 7,902 & - \\
\hline & TOTAL & 47,616 & 60,205 \\
\hline
\end{tabular}




\subsection{New Pump and Treat Facility Construction Estimate}

Table 11-2 provides a divisional breakdown of the estimated NPTF construction costs. This estimate is based upon the NPTF $90 \%$ design. This estimate covers the cost of constructing the facility and connecting to existing utilities. Operations and D\&D costs for the NPTF are covered in the overall project baseline cost identified in the previous section.

Table 11-2. New Pump and Treat Facility 90\% construction cost estimate.

\begin{tabular}{lrr}
\hline \multicolumn{1}{c}{ Operation } & \multicolumn{2}{c}{ Cost $\$$} \\
\hline Site Work & 55,975 \\
Concrete & & 89,693 \\
Building/Enclosure & 160,319 \\
$\quad$ Structure & 87,306 & \\
HVAC & 27,090 & \\
Well Head Enclosures & 45,923 & \\
Process System & & \\
$\quad$ Equipment & 117,844 & \\
$\quad$ Instrumentation and Control & 142,500 & \\
$\quad$ Internal Piping & 70,911 & \\
$\quad$ Influent Piping & 136,819 & \\
Effluent Piping & 64,385 & 104,569 \\
$\quad$ Well Pumps & 79,645 & $1,022,660$ \\
Utilities & & 161,507 \\
Subtotal Direct Construction Cost & \\
Contingency (20\%) & & 250,000 \\
Reinjection Well and Monitoring Well & & 174,728 \\
Construction/Project Management & \\
TOTAL & & $1,608,895$ \\
\hline a. Direct Construction costs do not include O\&M contractor adders. & \\
\hline
\end{tabular}

\subsection{Schedule}

The documents submitted to the EPA and IDHW as deliverables are presented in Table 11-3 with their corresponding submittal dates in accordance with Section XII of the Federal Facility Agreement and Consent Order (FFA/CO) (DOE-ID 1991). Milestone deliverable dates presented in Table 11-3 were established in the RD/RA SOW (DOE-ID 1997b), and, where applicable, are presented as modified by subsequent agency agreement. This table and the subsequent schedule (see Figure 11-1) only include deliverables up through the initiation of the remedial action.

Documents will have expedited and nonexpedited review and revision schedules. The review periods vary depending on the document. In general, all expedited draft primary documents have a 30-day review, and in some instances the draft final submittal has been eliminated. Draft primary documents (nonexpedited) have the standard 45-day review period. Secondary documents will have their standard 30-day review period. The DOE review will be concurrent with the EPA and IDHW review. Figure 11-1 is the schedule of activities for NPTF construction up through initiation of operations. 
Table 11-3. Operable Unit 1-07B deliverables log.

\begin{tabular}{|c|c|c|c|c|}
\hline Deliverables & $\begin{array}{c}\text { Submittal } \\
\text { Planned Date }\end{array}$ & $\begin{array}{c}\text { Submittal } \\
\text { Enforceable Date }\end{array}$ & $\begin{array}{l}\text { Review } \\
\text { Length } \\
\text { (days) }\end{array}$ & Document Type \\
\hline \multicolumn{5}{|l|}{ Treatability Studies } \\
\hline Phase I FDR (Draft) & $01 / 26 / 00$ & $01 / 31 / 00$ & 45 & Primary \\
\hline \multicolumn{5}{|c|}{ Medial Zone Groundwater Treatment } \\
\hline $\begin{array}{l}\text { Draft NPTF Functional and } \\
\text { Operational Requirements }\end{array}$ & $12 / 05 / 97$ & N/A & 45 & Disputable \\
\hline NPTF (30\%) Design & $09 / 29 / 98$ & $\mathrm{~N} / \mathrm{A}$ & 30 & Secondary \\
\hline Draft RD/RAWP-NPTF & $04 / 02 / 99$ & 04/30/99 & 45 & Primary \\
\hline NPTF RA Report & $08 / 02 / 01$ & $11 / 02 / 01$ & 45 & Primary \\
\hline $\begin{array}{l}\text { NPTF Annual Performance } \\
\text { Report }\end{array}$ & $\begin{array}{l}3 \text { months after end } \\
\text { of reporting period }\end{array}$ & $\mathrm{N} / \mathrm{A}$ & $\mathrm{N} / \mathrm{A}$ & Information \\
\hline $\begin{array}{l}\text { NPTF Operations and } \\
\text { Maintenance Report }\end{array}$ & $\mathrm{TBD}^{\mathrm{a}}$ & $\mathrm{TBD}^{\mathrm{a}}$ & 45 & Primary \\
\hline
\end{tabular}




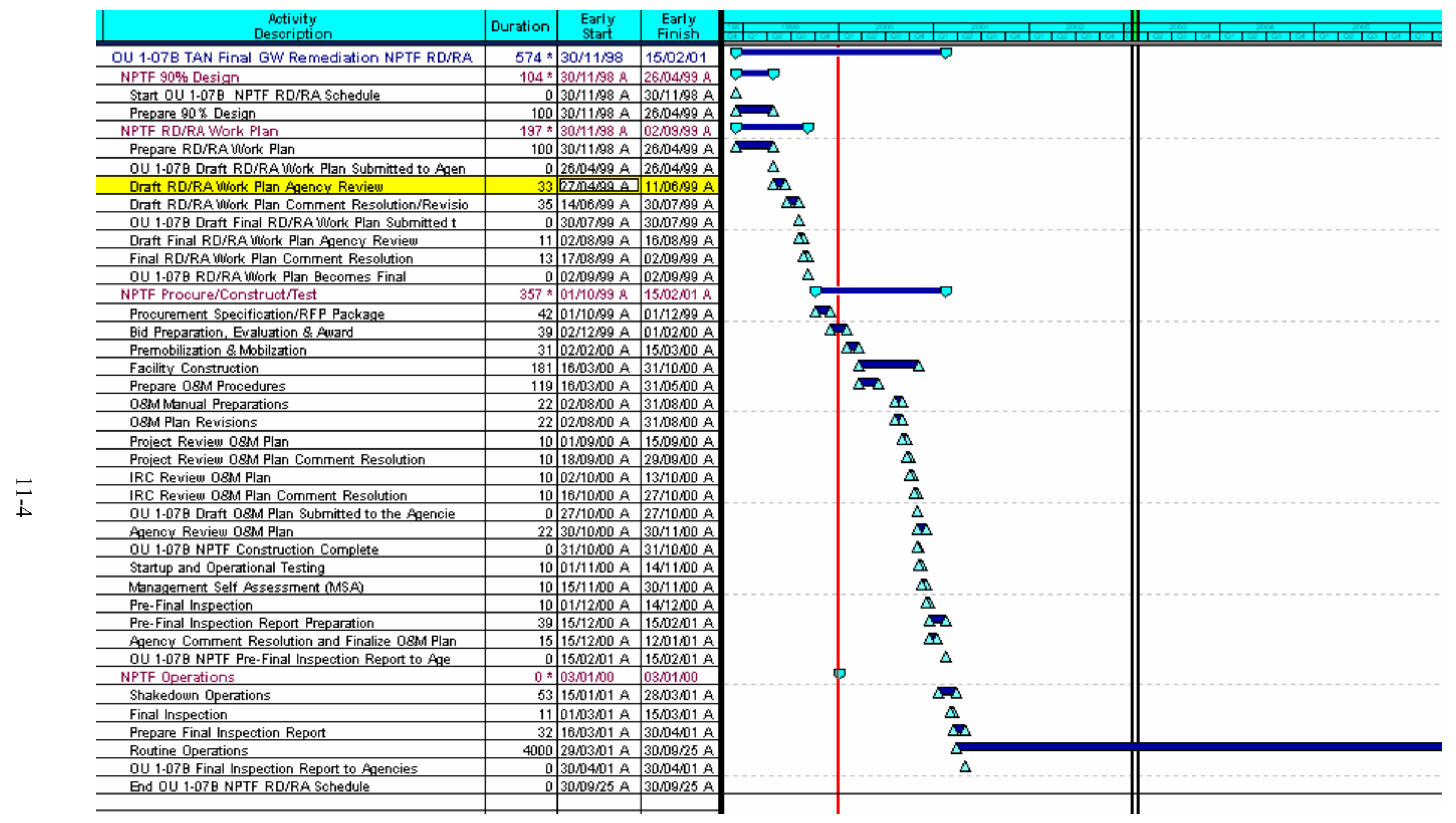

Figure 11-1. New Pump and Treat Facility construction schedule. 


\section{REFERENCES}

29 CFR 1910.120, 2003, "Hazardous Waste Operations and Emergency Response," Code of Federal Regulations, Office of the Federal Register, April 2003.

40 CFR 61.92, 2003, "National Emission Standards for Hazardous Air Pollutants—Standard," Code of Federal Regulations, Office of the Federal Register, July 2003.

40 CFR 61.93, 2003, "National Emission Standards for Hazardous Air Pollutants-Emission Monitoring and Test Procedures," Code of Federal Regulations, Office of the Federal Register, July 2003.

40 CFR 261.3, 2002, "Identification and Listing of Hazardous Waste," Code of Federal Regulations, Office of the Federal Register, February 2002.

40 CFR 262.11, 2002, "Hazardous Waste Determination," Code of Federal Regulations, Office of the Federal Register, February 2002.

40 CFR 264, Subpart I, 2002, "Use and Management of Containers," Code of Federal Regulations, Office of the Federal Register, April 2002.

40 CFR 264, Subpart J, 2002, "Tank Systems," Code of Federal Regulations, Office of the Federal Register, April 2002.

40 CRF 264.13, 2002, "General Waste Analysis," Code of Federal Regulations, Office of the Federal Register, April 2002.

40 CFR 264.18 (a), 2002, "Location Standards-Seismic Considerations," Code of Federal Regulations, Office of the Federal Register, April 2002.

40 CFR 264.18 (b), 2002, "Location Standards-Floodplains," Code of Federal Regulations, Office of the Federal Register, April 2002.

40 CFR 264.31, 2002, "Design and Operation of Facility," Code of Federal Regulations, Office of the Federal Register, April 2002.

40 CFR 264.32, 2002, "Required Equipment," Code of Federal Regulations, Office of the Federal Register, April 2002.

40 CFR 264.33, 2002, "Testing and Maintenance of Equipment," Code of Federal Regulations, Office of the Federal Register, April 2002.

40 CFR 264.34, 2002, "Access to Communications or Alarm System," Code of Federal Regulations, Office of the Federal Register, April 2002.

40 CFR 264.35, 2002, "Required Aisle Space," Code of Federal Regulations, Office of the Federal Register, April 2002.

40 CFR 264.37, 2002, “Arrangements with Local Authorities," Code of Federal Regulations, Office of the Federal Register, April 2002. 
40 CFR 264.111, 2002, “Closure Performance Standard," Code of Federal Regulations, Office of the Federal Register, 2002.

40 CFR 264.114, 2002, "Disposal or Decontamination of Equipment, Structures, and Soil," Code of Federal Regulations, Office of the Federal Register, April 2002.

40 CFR 761, 2002, "Polychlorinated Biphenyls (PCBS) Manufacturing, Processing, Distribution, in Commerce, and Use Prohibitions," Code of Federal Regulations, Office of the Federal Register, June 2003.

42 USC $\$ 6901$ et seq., United States Code, "Comprehensive Environmental Response, Compensation, and Liability Act of 1980 (CERCLA/Superfund)," United States Code, December 11, 1980.

DOE-ID, 1991, Federal Facility Agreement and Consent Order for the Idaho National Engineering Laboratory, Administrative Record No 1088-06-29-120, U.S. Department of Energy Idaho Operations Office; U.S. Environmental Protection Agency, Region 10; Idaho Department of Health and Welfare, December 4, 1991.

DOE-ID, 1993, Remedial Design and Remedial Action Guidance for the Idaho National Engineering Laboratory, DOE-ID/12584-152, Revision 1, U.S. Department of Energy Idaho Operations Office, October 1993.

DOE-ID, 1995, Record of Decision, Declaration for the Technical Support Facility Injection Well (TSF-05) and Surrounding Groundwater Contamination (TSF-23) and Miscellaneous No Action Sites Final Remedial Action, Operable Unit 1-07B, Waste Area Group 1, DOE/ID-10139, Idaho National Engineering and Environmental Laboratory, U.S. Department of Energy Idaho Operations Office, August 1995.

DOE-ID, 1997a, Well TSF-05 Surge and Stress Evaluation Report for Operable Unit 1-07B, DOE/ID-10558, U.S. Department of Energy Idaho Operations Office, February 1997.

DOE-ID, 1997b, Remedial Design Remedial Action Scope of Work Test Area North Final Groundwater Remediation Operable Unit 1-07B, DOE/ID-10522, Revision 5, U.S. Department of Energy Idaho Operations Office, August 1997.

DOE-ID, 1997c, Technology Evaluation Work Plan Test Area North Final Groundwater Remediation Operable Unit 1-07B, DOE/ID-10562, U.S. Department of Energy Idaho Operations Office, March 1997.

DOE-ID, 2000, New Pump and Treat Facility Remedial Design Test Area North Operable Unit 1-07B, DOE/ID-10661, Revision 1, U.S. Department of Energy Idaho Operations Office, March 2000.

DOE-ID, 2001a, Remedial Design/Remedial Action Scope of Work, DOE/ID-10905, Revision 1, U.S. Department of Energy Idaho Operations Office, November 2001.

DOE-ID, 2001b, Record of Decision Amendment: Technical Support Facility Injection Well (TSF-05) and Surrounding Groundwater Contamination (TSF-23) and Miscellaneous No Action Sites, Final Remedial Action, DOE/ID-10139, Amendment, Revision 0, U.S. Department of Energy Idaho Operations Office, U.S. Environmental Protection Agency, Idaho Department of Environmental Quality, September 2001. 
DOE-ID, 2002, Quality Assurance Project Plan for Waste Area Groups 1, 2, 3, 4, 5, 6, 7, 10, and Inactive Sites, Revision 7, U.S. Department of Energy Idaho Operations Office, September 2002.

DOE-ID, 2003a, New Pump and Treat Facility Operations and Maintenance Plan for Test Area North Final Groundwater Remediation Operable Unit 1-07B, DOE/ID-10684, Revision 3, U.S. Department of Energy Idaho Operations Office, September 2003.

DOE-ID, 2003b, Monitored Natural Attenuation Operations, Monitoring, and Maintenance Plan for Test Area North, Operable Unit 1-07B, DOE/ID-11066, Revision 0, U.S. Department of Energy Idaho Operations Office, June 2003.

DOE-ID, 2003c, Idaho National Engineering and Environmental Laboratory Waste Acceptance Criteria, DOE/ID-01-10381, Revision 18, U.S. Department of Energy Idaho Operations Office, May 2003.

IDAPA 37.03.03, 2003, "Rules for the Construction and Use of Injection Wells," Idaho Administrative Procedures Act, Idaho Department of Water Resources, May 2003.

IDAPA 58.01.01.585, 1995, “Toxic Air Pollutants Non-carcinogenic Increments," Idaho Administrative Procedures Act, Idaho Department of Environmental Quality, June 30, 1995.

IDAPA 58.01.01.586, 1995, “Toxic Air Pollutants Carcinogenic Increments," Idaho Administrative Procedures Act, Idaho Department of Environmental Quality, June 30, 1995.

IDAPA 58.01.01.650, 1994, "Rules for the Control of Fugitive Dust," Idaho Administrative Procedures Act, Idaho Department of Environmental Quality," May 1, 1994.

IDAPA 58.01.01.651, 1994, "General Rules,” Idaho Administrative Procedures Act, Idaho Department of Environmental Quality," May 1, 1994.

INEEL, 1997a, Waste Certification Plan for the Environmental Restoration Program, Idaho National Engineering and Environmental Laboratory, October 1997.

INEEL, 1997b, Explanation of Significant Differences from the Record of Decision for the Technical Support Facility Injection Well (TSF-05) and Surrounding Groundwater Contamination (TSF-23) and Miscellaneous No Action Sites, Final Remedial Action, Operable Unit 1-07B, Waste Area Group 1, Idaho National Engineering and Environmental Laboratory, INEEL/EXT-97-00931, Revision 0, Idaho National Engineering and Environmental Laboratory, November 1997.

INEEL, 1998, Well Characterization and Evaluation Report Supporting Functional and Operational Requirements for the New Pump and Treat Facility at Test Area North Operable Unit 1-07B, INEEL/EXT-97-01356, Revision 0, Idaho National Engineering and Environmental Laboratory, January 1998.

INEEL, 2002a, Waste Management Plan for Test Area North Final Groundwater Remediation, INEEL/EXT-98-00267, Revision 4, Idaho National Engineering and Environmental Laboratory, May 2002.

INEEL, 2002b, Interim Decontamination Plan for Operable Unit 1-07B, INEEL/EXT-97-01287, Revision 4, Idaho National Engineering and Environmental Laboratory, May 2002. 
INEEL, 2002c, Test Area North Operable Unit 1-07B Final Groundwater Remedial Action Health and Safety Plan, INEEL/EXT-99-00020, Revision 2, Idaho National Engineering and Environmental Laboratory, November 2002.

PLN-114, 2003, INEEL Emergency Plan/RCRA Contingency Plan, Revision 20, Manual 16A-Emergency Preparedness, August 2003. 


\section{Appendix A \\ Compliance with Regulatory Requirements}


A-2 


\section{Appendix A}

\section{Compliance with Regulatory Requirements}

Table A-1. Compliance with regulatory requirements.

\begin{tabular}{|c|c|c|}
\hline Category & Type & Regulatory Requirements \\
\hline \multirow{4}{*}{$\begin{array}{l}\text { Air Discharges } \\
\text { (Carcinogens and } \\
\text { Noncarcinogens) }\end{array}$} & \multirow[t]{4}{*}{ Chemical } & Idaho Toxic Air Pollutants \\
\hline & & $\begin{array}{l}\text { For all sources constructed or modified since May 1, 1994, the } \\
\text { net screening emissions levels (EL) and net acceptable ambient } \\
\text { concentrations (AAC) for non-carcinogens which are not } \\
\text { specifically controlled elsewhere in Idaho Administrative } \\
\text { Procedures Act (IDAPA) regulation will comply with the table } \\
\text { identified in IDAPA 58.01.01.585. }\end{array}$ \\
\hline & & $\begin{array}{l}\text { For all sources constructed or modified since May 1, 1994, the } \\
\text { net screening ELs and AAC for carcinogens which are not } \\
\text { specifically controlled elsewhere in these rules, are as provided } \\
\text { in the table identified in IDAPA 58.01.01.586. }\end{array}$ \\
\hline & & IDAPA 58.01.01.585 and IDAPA 58.01.01.586. \\
\hline
\end{tabular}

This requirement is only applicable for the medial zone remedy. The NPTF air emissions were modeled using an EPA approved air modeling program. Air emissions limits were established using the model results. The results of this modeling are documented in the NPTF Remedial Design (DOE-ID 2000) 
Table A-1. (continued).

\begin{tabular}{|c|c|c|c|}
\hline Category & Type & Regulatory Requirements & Implementation Strategy \\
\hline \multirow[t]{2}{*}{$\begin{array}{l}\text { Air Discharges } \\
\text { (Radionuclide) }\end{array}$} & Chemical & $\begin{array}{l}\text { National Emissions Standards for Hazardous Air Pollutants } \\
\text { (NESHAPS) }\end{array}$ & \multirow{2}{*}{$\begin{array}{l}\text { This requirement is only applicable for the medial zone } \\
\text { remedy. Emissions from the NPTF will be estimated } \\
\text { using calculations as allowed under the provisions of } \\
40 \text { CFR 61.93. The calculated emissions will be given to } \\
\text { INEEL Environmental Affairs personnel for inclusion in } \\
\text { the annual INEEL NESHAPs Report. }\end{array}$} \\
\hline & & $\begin{array}{l}\text { Emissions of radionuclides to the ambient air from DOE } \\
\text { facilities shall not exceed those amounts that would cause any } \\
\text { member of the public to receive in any year an effective dose } \\
\text { equivalent of } 10 \mathrm{mrem} / \text { year. }\end{array}$ & \\
\hline
\end{tabular}

\section{CFR 61.92}

Establishes standards and requirements for operations of the DOE and DOE contractors with respect to protection of members of the public and the environment against undue risk from radiation. Includes narrative and numerical standards (air and water) for management of radioactive liquid effluent and radiation protection of the public. In addition, the Order provides radiological protection requirements and guidelines for cleanup of residual radioactive material and management of the resulting wastes and residues, and release of property.

\section{DOE Order 5400.5 (To Be Considered)}

\section{Air Discharges} (Monitoring)
Action

Continuously monitor radionuclide emissions per the requirements in 40 CFR 61.93, if the discharge of radionuclides without pollution control equipment could cause an effective dose equivalent in excess of $.1 \mathrm{mrem} / \mathrm{yr}$. If continuous emissions modeling is not required, periodically perform confirmatory measurements to verify the low emissions.

\author{
40 CFR 61.93
}

This requirement is only applicable to the medial zone remedy. Annual radionuclide emissions from the NPTF will be conservatively calculated using the following parameters:

- Overall quantity of waste processed

- $\quad$ Average radionuclide concentration (i.e., tritium)

- Air stream flow rate.

The emissions will then be included in a site wide model to determine the effective dose equivalent for the nearest public receptor. If predicted uncontrolled emissions are less than .1 mrem/yr, then uncontrolled emissions will be periodically estimated and documented as outlined in the NPTF O\&M Plan (DOE-ID 2003). 
Table A-1. (continued).

\begin{tabular}{ccll}
\hline Category & Type & \multicolumn{1}{c}{ Regulatory Requirements } & \multicolumn{1}{c}{ Implementation Strategy } \\
\hline Fugitive Dust & Action & $\begin{array}{l}\text { All reasonable precautions will be taken to prevent the } \\
\text { generation of fugitive dust. IDAPA 58.01.01.651 identifies } \\
\text { examples of reasonable precautions for preventing fugitive dust. }\end{array}$ & $\begin{array}{l}\text { During construction activities, all reasonable precautions } \\
\text { will be taken to minimize fugitive dust through } \\
\text { application of engineering controls. Potential options } \\
\text { include: }\end{array}$
\end{tabular}

\section{IDAPA 58.01.01.650 and .651}

\section{Hazardous Waste Action} Determination

General Waste

Analysis
A person who generates a solid waste must determine if the waste is a hazardous waste by using the following method:

1. Determine if the waste is excluded under (40 CFR 261.4)

2. Determine if the waste is listed as a hazardous waste in 40 CFR 261, Subpart D

3. For the purposes of compliance with 40 CFR part 268 , or if the waste is not listed in subpart D of 40 CFR part 261, the generator must then determine whether the waste is identified in subpart C (characteristic) of 40 CFR part 261.

IDAPA 58.01.05.006 \{40 CFR 262.11\}

General facility standards require that operators of a facility must obtain chemical and physical analyses of a representative sample of each hazardous waste to be treated, stored, or disposed of at the facility prior to treatment, storage, or disposal. The analysis may include existing published or documented data on the hazardous waste or on hazardous waste generated from a similar process. At a minimum, the analysis must contain all the information which must be known to treat, store, or dispose of the waste in accordance with this part and part 268 of this chapter.

IDAPA 58.01.05.008 \{40 CFR 264.13\}
- Use of water sprays and dust suppressants

- Halting construction activities during periods of high winds.

Any waste streams generated during the remediation process for storage and/or disposal will have a hazardous waste determination performed. If needed, sampling will be conducted in accordance with a task specific sampling and analysis plan. All generated waste will be packaged, handled, and stored in accordance with the Phase $\mathrm{C}$ Waste Management Plan (INEEL 2002). Waste minimization activities will be implemented in accordance with the INEEL Reusable Property, Recycle Materials and Waste Acceptance Criteria. Trained personnel will inspect and ensure the CERCLA Waste Storage Unites are in compliance with all applicable regulations.

Waste stream management requirements are based on a waste evaluation supported by a project sampling and analysis plan and/or process knowledge. This information will provide the basis for determining: container requirements, storage requirements, labeling requirements, and treatment and disposal requirements. All waste (both radionuclide and VOC) generated during remediation operations will be managed through facility procedures in accordance with the Phase C Waste Management Plan (INEEL 2002). 
Table A-1. (continued).

\begin{tabular}{lcl}
\hline \multicolumn{1}{c}{ Category } & Type & \multicolumn{1}{c}{ Regulatory Requirements } \\
\hline $\begin{array}{l}\text { General Facility } \\
\text { Standards. }\end{array}$ & Location & $\begin{array}{l}\text { Seismic considerations for portions of new facilities where } \\
\text { treatment, storage, or disposal of hazardous waste will be }\end{array}$ \\
(Site Selection) & & $\begin{array}{l}\text { conducted must not be located within } 61 \text { meters (200 feet) of a } \\
\text { fault which has had displacement in Holocene time. A facility } \\
\text { located in a 100-year floodplain must be designed, constructed, } \\
\text { operated, and maintained to prevent washout or any hazardous } \\
\text { waste by a 100-year flood, unless the owner or operator can } \\
\text { demonstrate to the Regional Administrator's satisfaction that: }\end{array}$
\end{tabular}

(i) Procedures are in effect which will cause the waste to be removed safely, before flood waters can reach the facility, to a location where the wastes will not be vulnerable to flood waters; or

(ii) For existing surface impoundments, waste piles, land treatment units, landfills, and miscellaneous units, no adverse effects on human health or the environment will result if washout occurs.

\section{IDAPA 58.01.05.008 [40 CFR 264.18(a) and (b)]}

General Facility Action Standards (Preparedness and Prevention)
Treatment, Storage, and Disposal (TSD) operators must design, construct, maintain and operate facilities to minimize the possibility of fire, explosion or any unplanned sudden or non-sudden release of hazardous waste to air, soil, or surface water which might threaten human health or the environment

IDAPA 58.01.05.008 \{40 CFR 264.31 through .35 and .37\}
Implementation Strategy

Construction activities involving siting a facility will take into consideration:

- $\quad$ Site hydrology, geology, and waste characteristics;

- Compliance with the NEPA process;

- $\quad$ Potential sites must be evaluated for natural hazards such as floods, erosion, tornadoes, earthquakes, and volcanoes;

- $\quad$ Areas subject to surface geological processes (i.e., mass wasting, erosion, slumping, landslides, and weathering) which significantly affect the ability of the disposal facility to meet the performance objectives will be avoided.

Current area designations show that the 1-07B Project Area is not within a 100 -year floodplain.

New and existing facilities will continue to be designed, inspected and operated in compliance with site procedures and the requirements of this section. New treatment systems and any modifications to existing facilities as well as current operations will consider the design and operational requirements of these sections when developing the design requirements. 
Table A-1. (continued).

\begin{tabular}{|c|c|c|c|}
\hline Category & Type & Regulatory Requirements & Implementation Strategy \\
\hline \multirow{6}{*}{$\begin{array}{l}\text { Closure } \\
\text { Performance } \\
\text { Standards }\end{array}$} & \multirow[t]{6}{*}{ Action } & The owner or operator must close the facility in a manner that: & \multirow{3}{*}{$\begin{array}{l}\text { Once remediation activities have achieved compliance } \\
\text { with remediation goals, closeout procedures will be } \\
\text { implemented. An evaluation of the equipment and storage } \\
\text { areas will determine closure requirements and } \\
\text { management of the materials, pump and treat equipment, } \\
\text { and associated ancillary piping. Emphasis will be placed } \\
\text { on minimal site O\&M at completion of closure. }\end{array}$} \\
\hline & & 1. Minimizes the need for further maintenance, & \\
\hline & & $\begin{array}{l}\text { 2. Controls, minimizes or eliminates, to the extent necessary to } \\
\text { protect human health and the environment, post-closure } \\
\text { escape of hazardous waste, hazardous constituents, leachate, } \\
\text { contaminated run-off, or hazardous waste decomposition } \\
\text { products to the ground or surface waters or to the atmosphere, }\end{array}$ & \\
\hline & & and & \multirow{3}{*}{$\begin{array}{l}\text { All equipment, materials, and associated debris generated } \\
\text { during project closeout will be adequately characterized } \\
\text { to determine waste management requirements. }\end{array}$} \\
\hline & & 3. Complies with the closure requirements of this subpart. & \\
\hline & & IDAPA 58.01.05.008 \{40 CFR 264.111\} & \\
\hline
\end{tabular}

During the partial and final closure periods, all contaminated equipment, structures and soils must be properly disposed of or decontaminated unless otherwise specified in Sections 264.197, 264.228, 264.258, 264.280 or Section 264.310. By removing any hazardous wastes or hazardous constituents during partial and final closure, the owner or operator may become a generator of hazardous waste and must handle that waste in accordance with all applicable requirements of part 262 of this chapter.

IDAPA 58.01.05.008 \{40 CFR 264.114\} 
Table A-1. (continued).

\begin{tabular}{|c|c|c|c|}
\hline Category & Type & Regulatory Requirements & Implementation Strategy \\
\hline $\begin{array}{l}\text { Container } \\
\text { Management }\end{array}$ & Action & $\begin{array}{l}\text { 1. Remediation wastes will be kept in containers meeting the } \\
\text { requirements of } 40 \text { CFR } 264.171 \text {; } \\
\text { 2. Wastes will be stored with compatible containers; } \\
\text { 3. Containers will be properly managed; and } \\
\text { 4. The storage facility will be subject to inspections under } \\
40 \text { CFR } 264.174 \text {. } \\
\text { 5. The storage area containment system will be in accordance } \\
\text { with } 40 \text { CFR } 264.175 \text {. } \\
\text { IDAPA } 58.01 .05 .008\{40 \text { CFR } 264 \text { Subpart I }\}\end{array}$ & $\begin{array}{l}\text { Characterization results via process knowledge or } \\
\text { analytical results will dictate the packaging requirements, } \\
\text { determine storage requirements, and compatibility with } \\
\text { other wastes. Waste containers will be properly labeled } \\
\text { and managed in accordance with existing operating } \\
\text { procedures. All containerized waste will be subject to } \\
\text { RCRA storage facility inspection requirements. If } \\
\text { required, the storage containers will be stored within the } \\
\text { CERCLA Waste Storage Area. }\end{array}$ \\
\hline
\end{tabular}

Containers used to transport water extracted during groundwater sampling, will not be double walled containers. If water is stored in these containers ( $>3$ days) they will be placed in a container storage area with secondary containment.

Any new treatment systems and any future facility modifications will be designed to provide adequate containment.

These requirements will be covered and implemented through the Phase C Waste Management Plan (INEEL 2002) and respective Phase C Remedial Designs.

Tank Systems Action The tank system utilized in processing the remediation waste streams generated during remediation operations will comply with the tank system requirements under 40 CFR 264 Subpart J which includes:

1. Assessment of the tank's system integrity;

2. Containment and detection of releases;

3. General operating requirements;

4. Inspections;

5. Response to leaks or spills; and

6. Closure and Post-Closure care.

IDAPA 58.01.05.008 $\{40$ CFR 264 Subpart J $\}$

The tank systems will be inspected once per operating day. The inspection will check for visible and leakage and signs of corrosion, and will check the leak detection system for indications of leakage.

Any new treatment systems and any future facility modifications will be designed to address the need for adequate containment and regulatory requirements.

Any new tanks used in new remediation facilities that are designated as a tank system, will be certified by an independent qualified registered professional engineer attesting that the tank system has sufficient structural integrity and is acceptable for storing and treating hazardous waste. 
Table A-1. (continued).

\begin{tabular}{cccc}
\hline Category & Type & Regulatory Requirements & Implementation Strategy \\
\hline Land Disposal & Action & IDAPA Regulation 58.01.05.011 identifies that all of & Wastes generated as a result of remediation efforts will be
\end{tabular}

Restrictions

40 CFR Part 268 and all Subparts are herein incorporated by reference as provided in 40 CFR, revised as of July 1, 1994, except for 40 CFR Parts 268.5, 268.6, 268.42(b) and 268.44. Except as specifically provided otherwise in this part or part 261 of this chapter, the requirements of this part apply to persons who generate or transport hazardous waste and owners and operators of hazardous waste treatment, storage, and disposal facilities. Restricted wastes may continue to be land disposed as follows:

1. Where persons have been granted an extension to the effective date of a prohibition under subpart $\mathrm{C}$ of this part or pursuant to Section 268.5, with respect to those wastes covered by the extension;

2. Where persons have been granted an exemption from a prohibition pursuant to a petition under Section 268.6, with respect to those wastes and units covered by the petition;

3. Wastes that are hazardous only because they exhibit a hazardous characteristic, and which are otherwise prohibited from land disposal under this part, are not prohibited from land disposal if the wastes:

a. Are disposed into a nonhazardous or hazardous injection well as defined in 40 CFR 144.6(a); and

b. Do not exhibit any prohibited characteristic of hazardous waste at the point of injection; and

c. If at the point of generation the injected wastes include D001 High TOC subcategory wastes or D012-D017 pesticide wastes that are prohibited under Section 148.17(c) of this chapter, those wastes have been treated to meet the treatment standards of Section 268.40 before injection.

\section{IDAPA 58.01.05.01}

Water Quality Action

Contaminated groundwater may not be injected back into the aquifer in which it came unless the groundwater is treated to substantially reduce hazard constituents prior to such reinjection.

Section 3020 of RCRA. characterized for determining management requirements. Additionally, each waste stream will be evaluated to determine the applicability of land disposal restrictions (LDRs). Waste streams subject to LDRs will be segregated and consolidated with compatible waste streams, as appropriate, when similar treatment technologies can be utilized. Waste streams generated from implementation of treatment technologies will be captured and appropriately managed based on classification

Any extracted groundwater obtained during performance of the OU 1-07B remedial activities will be processed through the NPTF prior to reinjection. Processing through the NPTF will substantially reduce the hazardous constituents. 
Table A-1. (continued).

\begin{tabular}{lcl}
\hline \multicolumn{1}{c}{ Category } & Type & \multicolumn{1}{c}{ Regulatory Requirements } \\
\hline $\begin{array}{l}\text { Water Quality } \\
\text { (Underground } \\
\text { Injection Control) }\end{array}$ & Action & $\begin{array}{l}\text { No chemical contaminants at concentrations above MCLs, or } \\
\text { above the contaminant concentration of the receiving water can } \\
\text { be injected into the aquifer. No radionuclides above MCLs, or } \\
\text { hazardous waste, can be injected into the aquifer. }\end{array}$
\end{tabular}

\section{IDAPA 37.03.03}

Water Quality Action (Monitoring)
Monitoring, record keeping and reporting may be required if the well could adversely affect a drinking water source or if injecting a contaminant that could have an unacceptable effect upon the quality of the groundwaters of the state. The state may require where appropriate, but is not limited to, the following:

1. Any injection authorized by the state shall be subject to monitoring and record keeping requirements as conditions of the permit;

2. The frequency of required monitoring shall be specified in the permit;

3. All monitoring tests and analysis required by permit conditions shall be performed in a state certified laboratory or other laboratory approved by the state;

4. Any field instrumentation used to gather data, when specified as a condition of the permit, shall be tested and maintained in such a manner as to ensure the accuracy of the data; and

5. All samples and measurements taken for the purpose of monitoring shall be representative of the monitoring activity and fluids injected.

IDAPA 37.03.03.055.01
Implementation Strategy

The design of the NPTF has incorporated the substantive requirements specified within this IDAPA regulation.

Any systems or components that inject materials into the aquifer during the remedial activities will meet these requirements as established in the individual work plans. Periodic monitoring will be performed to show compliance with this regulation. 
Table A-1. (continued).

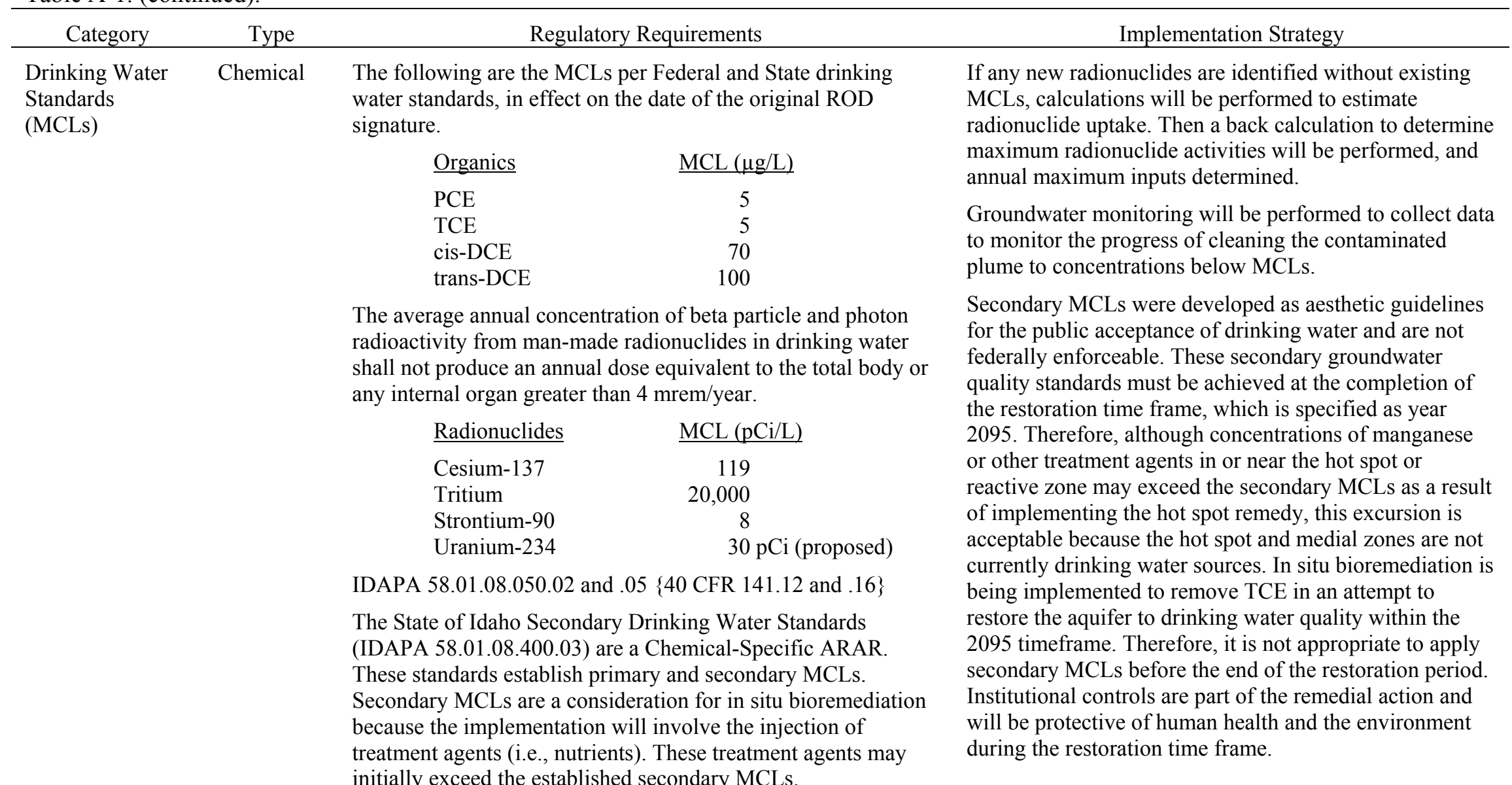

\footnotetext{
IDAPA 58.01.08.400.03
} 
Table A-1. (continued).

\begin{tabular}{lcll}
\hline \multicolumn{1}{c}{ Category } & Type & \multicolumn{1}{c}{ Regulatory Requirements } & \multicolumn{1}{c}{ Implementation Strategy } \\
\hline $\begin{array}{l}\text { Historic } \\
\text { Preservation }\end{array}$ & Location & $\begin{array}{l}\text { The Secretary of the Interior must be notified in writing } \\
\text { whenever DOE finds or is notified in writing by an appropriate } \\
\text { historical or archaeological authority that the activities in } \\
\text { connection with a project may cause irreparable loss or } \\
\text { destruction of significant scientific, prehistorical, historical, or } \\
\text { archaeological data. The DOE or the Department of Interior } \\
\text { must preserve any data that may be lost or destroyed. }\end{array}$ & $\begin{array}{l}\text { All areas within the hot spot and medial zone have been } \\
\text { surveyed and evaluated for historical preservation } \\
\text { resources. Any siting of new facilities or wells will be } \\
\text { surveyed and evaluated to determine if there will be any } \\
\text { impacts to historical sites. }\end{array}$ \\
& & \\
& 36 CFR 800.4(a)(1)(i)(iii)(a)(2) & \\
& 36 CFR 800.4(b) & \\
&
\end{tabular}




\section{A-1. REFERENCES}

IDAPA 58.01.01.585, 1995, “Toxic Air Pollutants Non-carcinogenic Increments," Idaho Administrative Procedures Act, Idaho Department of Environmental Quality, June 30, 1995.

IDAPA 58.01.01.586, 1995, “Toxic Air Pollutants Carcinogenic Increments," Idaho Administrative Procedures Act, Idaho Department of Environmental Quality, June 30, 1995.

36 CFR 800.4 (a), 2002, "Identification of Historic Properties-Determine Scope of Identification Efforts," Code of Federal Regulations, Office of the Federal Register, February 2002.

36 CFR 800.4 (b), 2002, "Identification of Historic Properties-Identify Historic Properties," Code of Federal Regulations, Office of the Federal Register, February 2002.

40 CFR 61.92, 2003, "National Emission Standards for Hazardous Air Pollutants-Standard," Code of Federal Regulations, Office of the Federal Register, July 2003.

40 CFR 61.93, 2003, "National Emission Standards for Hazardous Air Pollutants—Emission Monitoring and Test Procedures," Code of Federal Regulations, Office of the Federal Register, July 2003.

40 CFR 141.12, 2003, "Maximum Contaminant Levels for Total Trihalomethanes," Code of Federal Regulations, Office of the Federal Register, April 2003.

40 CFR 141.16, 2003, "Maximum Contaminant Levels for Beta Particle and Photon Radioactivity from Man-Made Radionuclides in Community Water Systems," Code of Federal Regulations, Office of the Federal Register, April 2003.

40 CFR 144.6, 2002, "Classification of Wells," Code of Federal Regulations, Office of the Federal Register, June 2002.

40 CFR 261, Subpart C, 2003, "Characteristics of Hazardous Waste," Code of Federal Regulations, Office of the Federal Register, September 2003.

40 CFR 261, Subpart D, 2003, "Lists of Hazardous Wastes," Code of Federal Regulations, Office of the Federal Register, September 2003.

40 CFR 261.4, 2003, "Identification and Listing of Hazardous Waste-Exclusions," Code of Federal Regulations, Office of the Federal Register, September 2003.

40 CFR 262.11, 2002, "Hazardous Waste Determination," Code of Federal Regulations, Office of the Federal Register, February 2002.

40 CFR 264, Subpart I, 2002, "Use and Management of Containers," Code of Federal Regulations, Office of the Federal Register, April 2002.

40 CFR 264, Subpart J, 2002, “Tank Systems," Code of Federal Regulations, Office of the Federal Register, April 2002.

40 CRF 264.13, 2002, "General Waste Analysis," Code of Federal Regulations, Office of the Federal Register, April 2002. 
40 CFR 264.18 (a), 2002, "Location Standards—Seismic Considerations," Code of Federal Regulations, Office of the Federal Register, April 2002.

40 CFR 264.18 (b), 2002, "Location Standards-Floodplains," Code of Federal Regulations, Office of the Federal Register, April 2002.

40 CFR 264.31, 2002, "Design and Operation of Facility," Code of Federal Regulations, Office of the Federal Register, April 2002.

40 CFR 264.32, 2002, "Required Equipment," Code of Federal Regulations, Office of the Federal Register, April 2002.

40 CFR 264.33, 2002, "Testing and Maintenance of Equipment," Code of Federal Regulations, Office of the Federal Register, April 2002.

40 CFR 264.34, 2002, “Access to Communications or Alarm System," Code of Federal Regulations, Office of the Federal Register, April 2002.

40 CFR 264.35, 2002, “Required Aisle Space,' Code of Federal Regulations, Office of the Federal Register, April 2002.

40 CFR 264.37, 2002, “Arrangements with Local Authorities," Code of Federal Regulations, Office of the Federal Register, April 2002.

40 CFR 264.111, 2002, "Closure Performance Standard," Code of Federal Regulations, Office of the Federal Register, 2002.

40 CFR 264.114, 2002, "Disposal or Decontamination of Equipment, Structures, and Soil," Code of Federal Regulations, Office of the Federal Register, April 2002.

40 CFR 264.171, 2002, "Condition of Containers," Code of Federal Regulations, Office of the Federal Register, April 2002.

40 CFR 264.174, 2002, "Inspections," Code of Federal Regulations, Office of the Federal Register, April 2002.

40 CFR 264.175, 2002, “Containment," Code of Federal Regulations, Office of the Federal Register, April 2002.

40 CFR 264.197, 2002, “Tank Systems - Closure and Post-Closure Care,” Code of Federal Regulations, Office of the Federal Register, April 2002.

40 CFR 264.228, 2002, "Surface Impoundments-Closure and Post-Closure Care," Code of Federal Regulations, Office of the Federal Register, April 2002.

40 CFR 264.258, 2002, "Waste Piles-Closure and Post-Closure Care," Code of Federal Regulations, Office of the Federal Register, April 2002.

40 CFR 264.280, 2002, "Land Treatment-Closure and Post-Closure Care," Code of Federal Regulations, Office of the Federal Register, April 2002. 
40 CFR 264.310, 2002, "Landfills_-Closure and Post-Closure Care," Code of Federal Regulations, Office of the Federal Register, April 2002.

40 CFR 268, 2002, "Land Disposal Restrictions," Code of Federal Regulations, Office of the Federal Register, April 2002.

DOE-ID, 2000, New Pump and Treat Facility Remedial Design Test Area North Operable Unit 1-07B, DOE/ID-10661, Revision 1, U.S. Department of Energy Idaho Operations Office, March 2000.

DOE-ID, 2003, New Pump and Treat Facility Operations and Maintenance Plan for Test Area North Final Groundwater Remediation Operable Unit 1-07B, DOE/ID-10684, Revision 3, U.S. Department of Energy Idaho Operations Office, September 2003.

DOE O 5400.5, 1993, "Radiation Protection of the Public and the Environment," Chg. 2, U.S. Department of Energy, January 1993.

IDAPA 37.03.03, 2003, "Rules for the Construction and Use of Injection Wells," Idaho Administrative Procedures Act, Idaho Department of Water Resources, May 2003.

IDAPA 37.03.03.055.01, 1993, "Monitoring, Record Keeping and Reporting RequirementsMonitoring," Idaho Administrative Procedures Act, Idaho Department of Water Resources, July 1993.

IDAPA 58.01.01.650, 1994, "Rules for the Control of Fugitive Dust," Idaho Administrative Procedures Act, Idaho Department of Environmental Quality," May 1, 1994.

IDAPA 58.01.01.651, 1994, “General Rules,” Idaho Administrative Procedures Act, Idaho Department of Environmental Quality, May 1, 1994.

IDAPA 58.01.05.006, 2003, "Standards Applicable to Generators of Hazardous Waste," Idaho Administrative Procedures Act, Idaho Department of Environmental Quality, May 2003.

IDAPA 58.01.05.008, 2003, "Standards for Owners and Operators of Hazardous Waste Treatment, Storage and Disposal Facilities," Idaho Administrative Procedures Act, Idaho Department of Environmental Quality, May 2003.

IDAPA 58.01.05.011, 2003, “Land Disposal Restrictions," Idaho Administrative Procedures Act, Idaho Department of Environmental Quality, May 2003.

IDAPA 58.01.08.050.02, 1993, “Organic Contaminants," Idaho Administrative Procedures Act, Idaho Department of Environmental Quality, October 1993.

IDAPA 58.01.08.050.05, 2002, "Microbiological Contaminants," Idaho Administrative Procedures Act, Idaho Department of Environmental Quality, March 2002.

IDAPA 58.01.08.400.03, 1993, "Secondary Maximum Contaminant Levels," Idaho Administrative Procedures Act, Idaho Department of Environmental Quality, October 1993.

INEEL, 2002, Waste Management Plan for Test Area North Final Groundwater Remediation, INEEL/EXT-98-00267, Revision 4, Idaho National Engineering and Environmental Laboratory, May 2002. 


\section{Appendix B \\ Agency Phase C Document Review Comments and Resolutions}


B-2 


\section{Appendix B-1 \\ Document Review Comments and Resolutions September 16, 1999}


B-4 


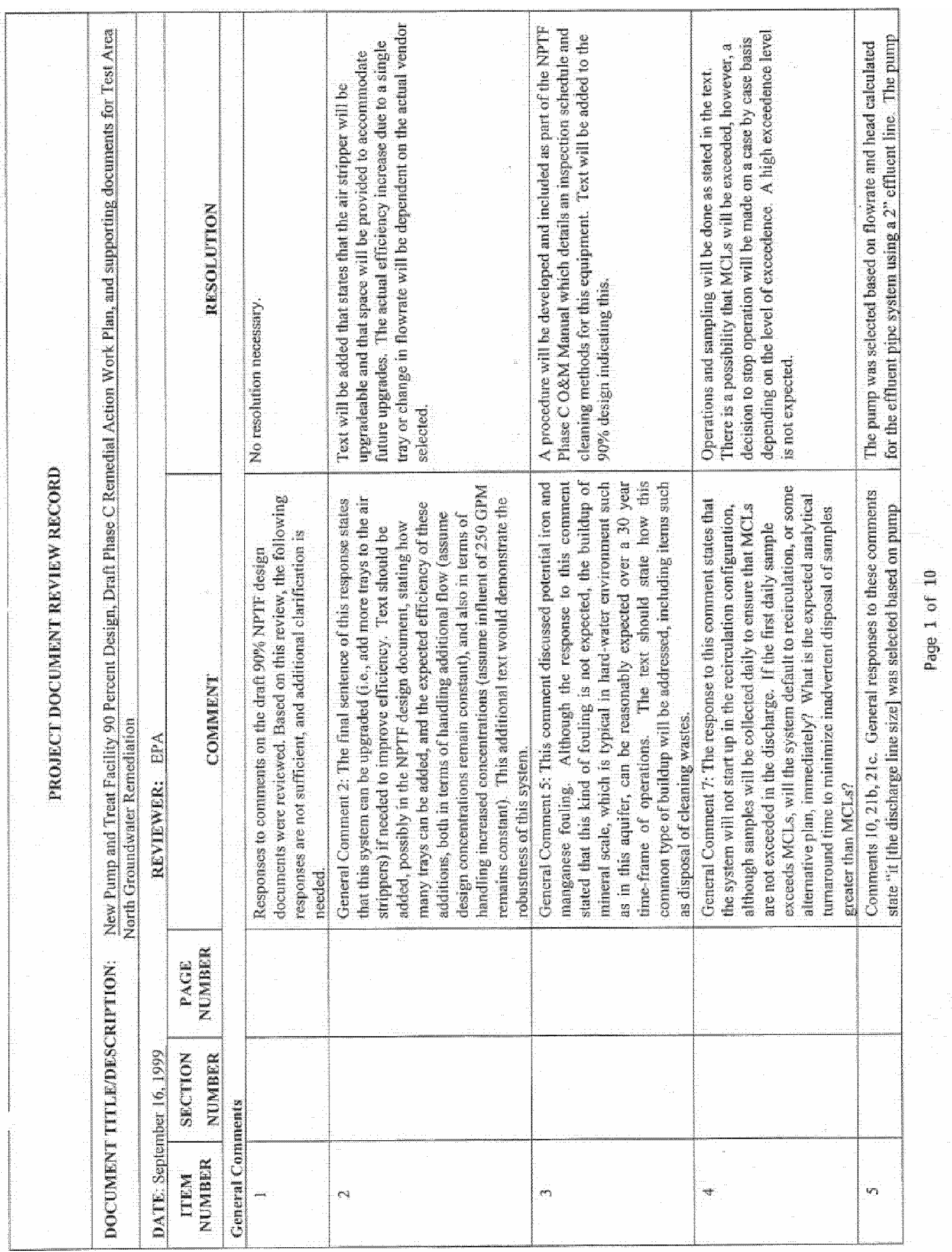




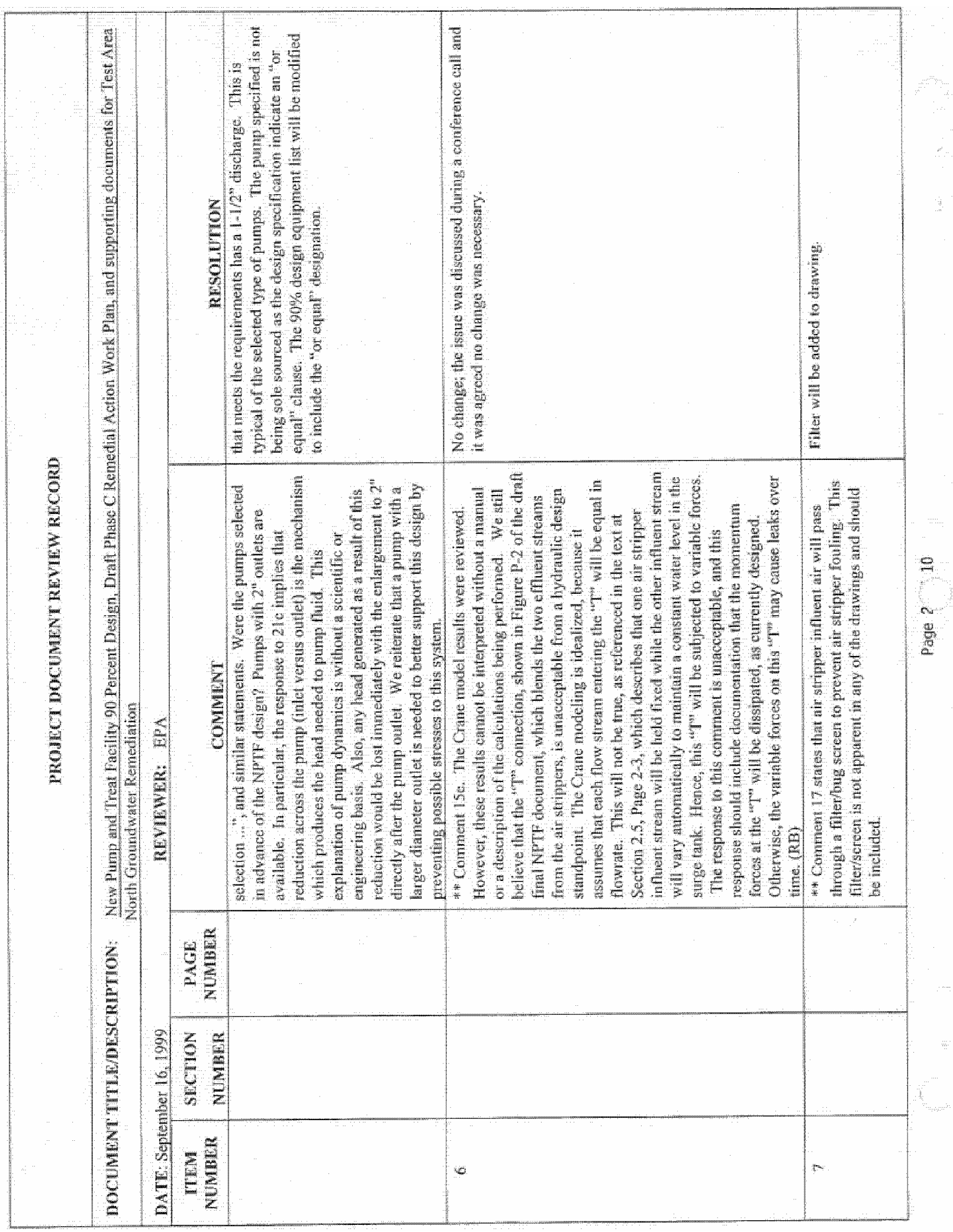




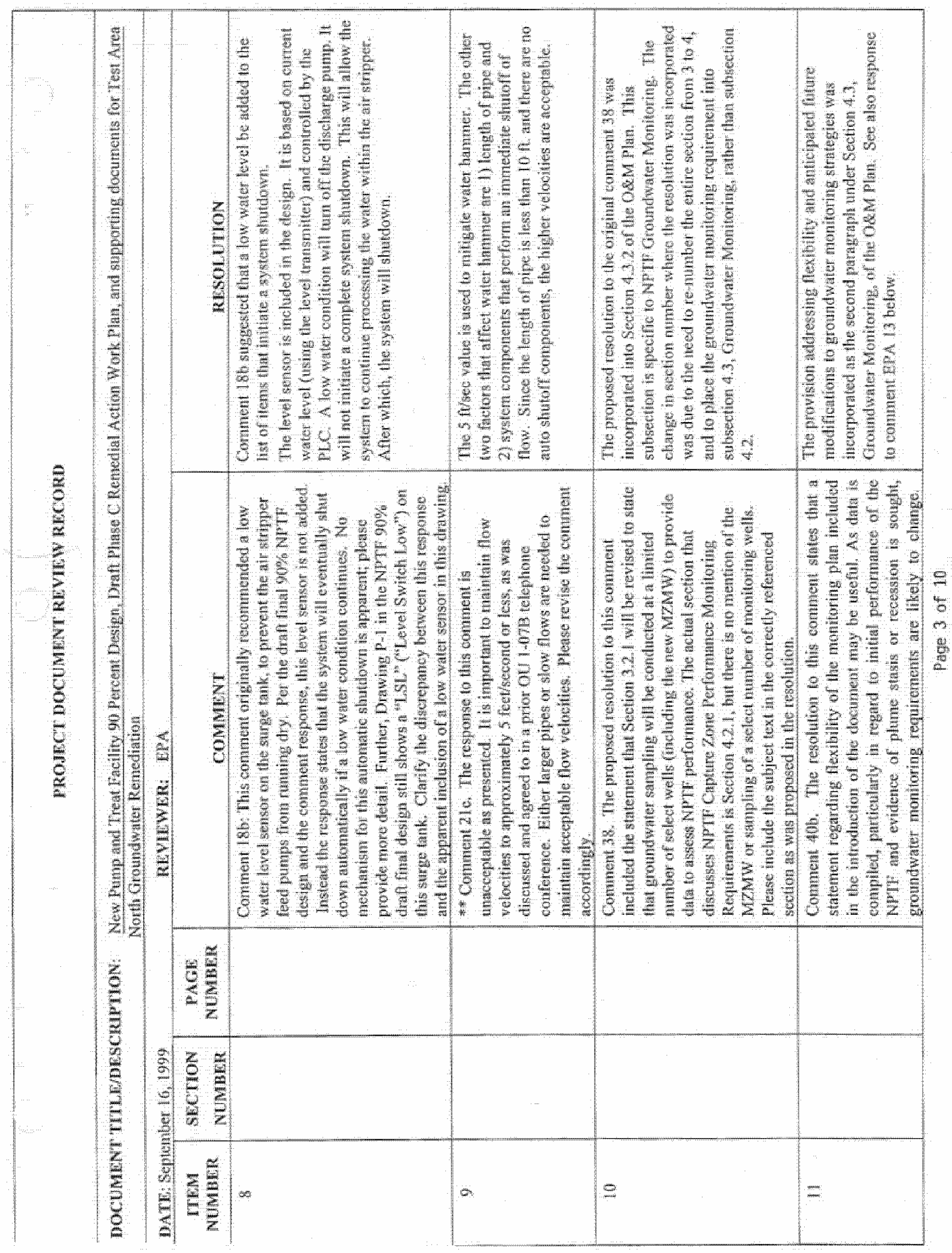




\begin{tabular}{|c|c|c|c|c|c|c|c|c|}
\hline \multirow{5}{*}{ 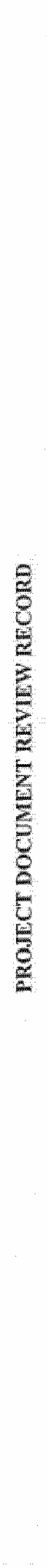 } & \multirow{5}{*}{ 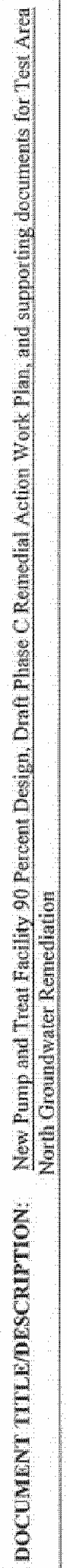 } & & $\begin{array}{l}3 \\
\frac{3}{3} \\
0 \\
3\end{array}$ & & 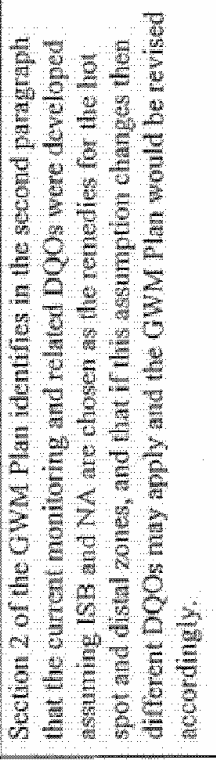 & 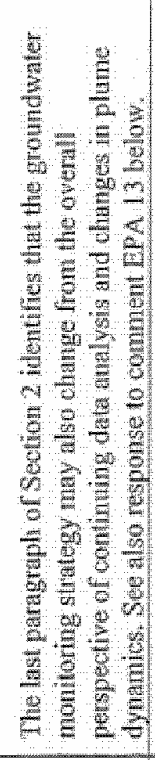 & 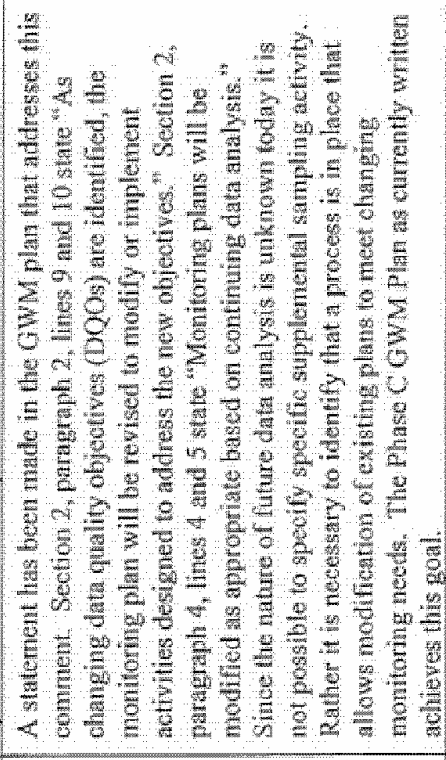 & 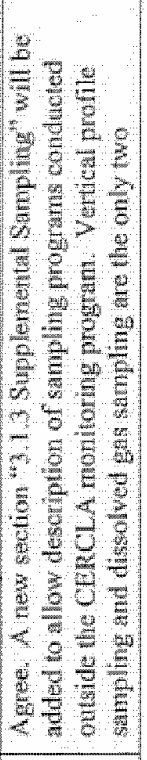 \\
\hline & & $\begin{array}{l}5 \\
\frac{5}{5} \\
\frac{5}{3} \\
\frac{5}{3}\end{array}$ & $\frac{5}{3}$ & 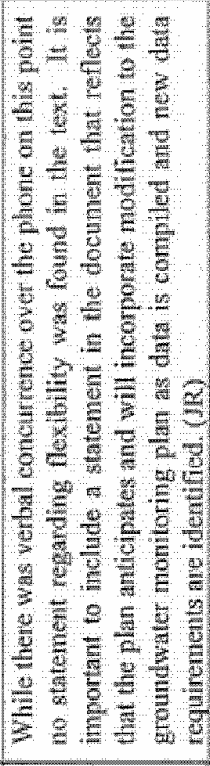 & 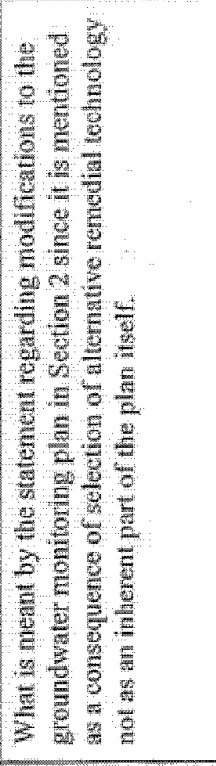 & & 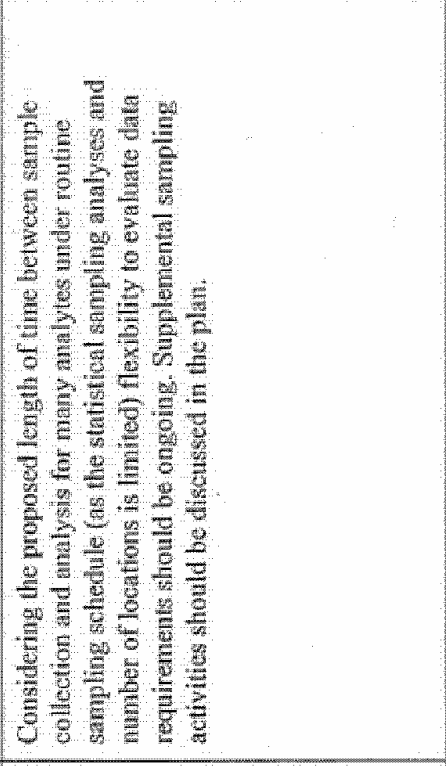 & 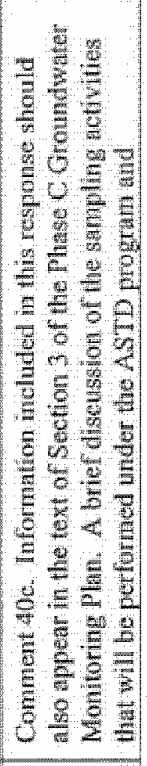 \\
\hline & & & $\frac{5}{E}$ & & & & & \\
\hline & & 9 & $\left.\frac{3}{3}\right)$ & & & & & \\
\hline & & a & $\frac{E}{E}$ & & $=$ & & $=$ & \pm \\
\hline
\end{tabular}




\begin{tabular}{|c|c|c|c|c|c|c|c|c|}
\hline \multirow{5}{*}{ 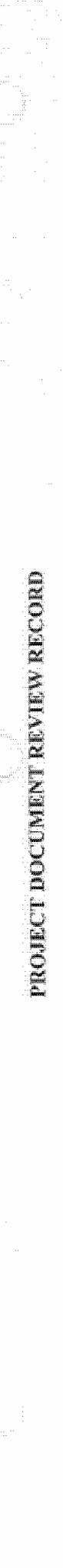 } & \multirow{5}{*}{ 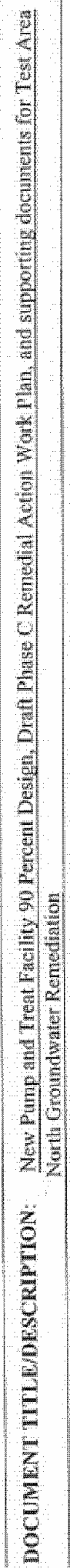 } & & $\begin{array}{l}3 \\
5 \\
5 \\
0 \\
0 \\
3\end{array}$ & 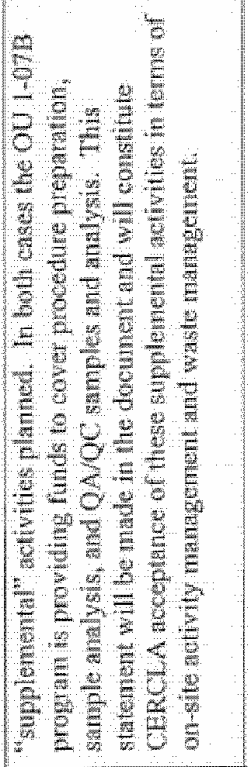 & 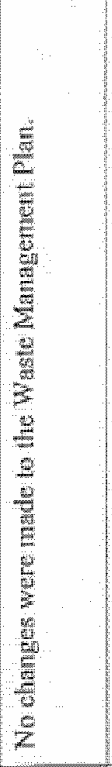 & 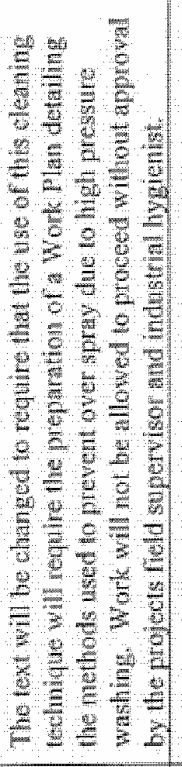 & 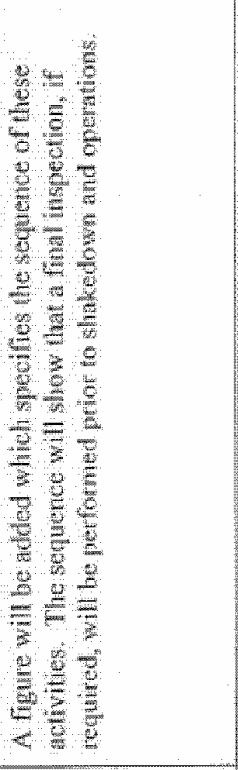 & 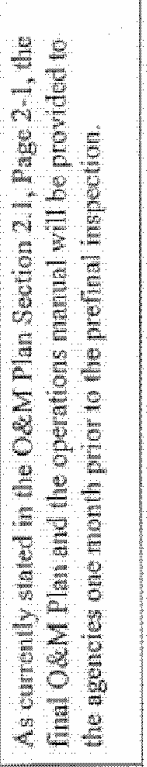 \\
\hline & & $\begin{array}{l}\frac{3}{4} \\
\frac{3}{2} \\
\frac{2}{2} \\
\frac{3}{3}\end{array}$ & $\frac{2}{2}$ & 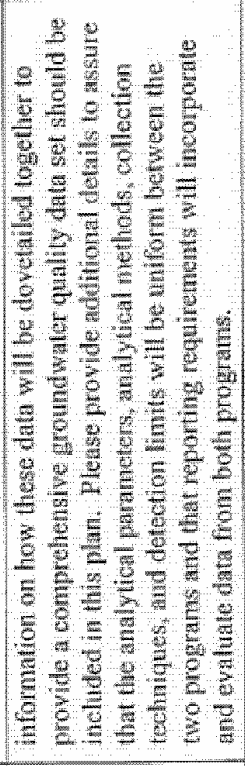 & 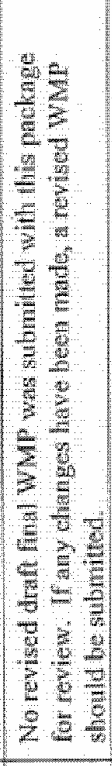 & 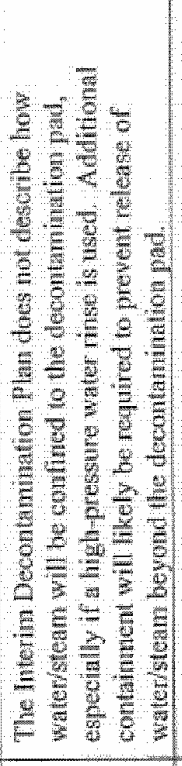 & 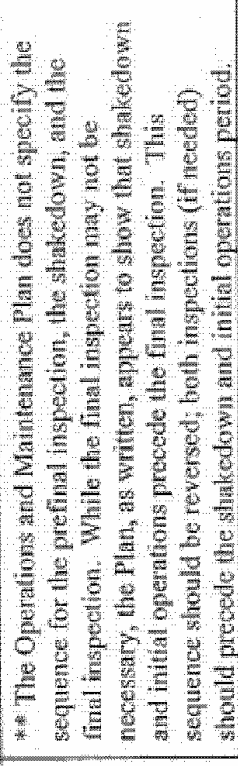 & 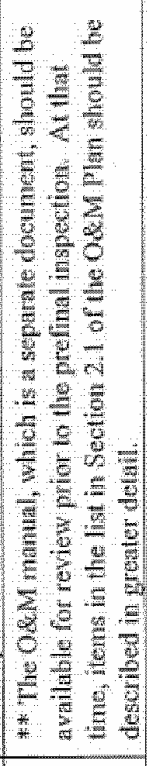 \\
\hline & & & $\frac{5}{3}$ & & & & & \\
\hline & & $\begin{array}{l}8 \\
8 \\
5\end{array}$ & $\frac{5}{8}$ & & & & & \\
\hline & & $\frac{5}{5}$ & $=\frac{E}{E}$ & & $=$ & $1 \div$ & $=$ & $1 \approx$ \\
\hline
\end{tabular}




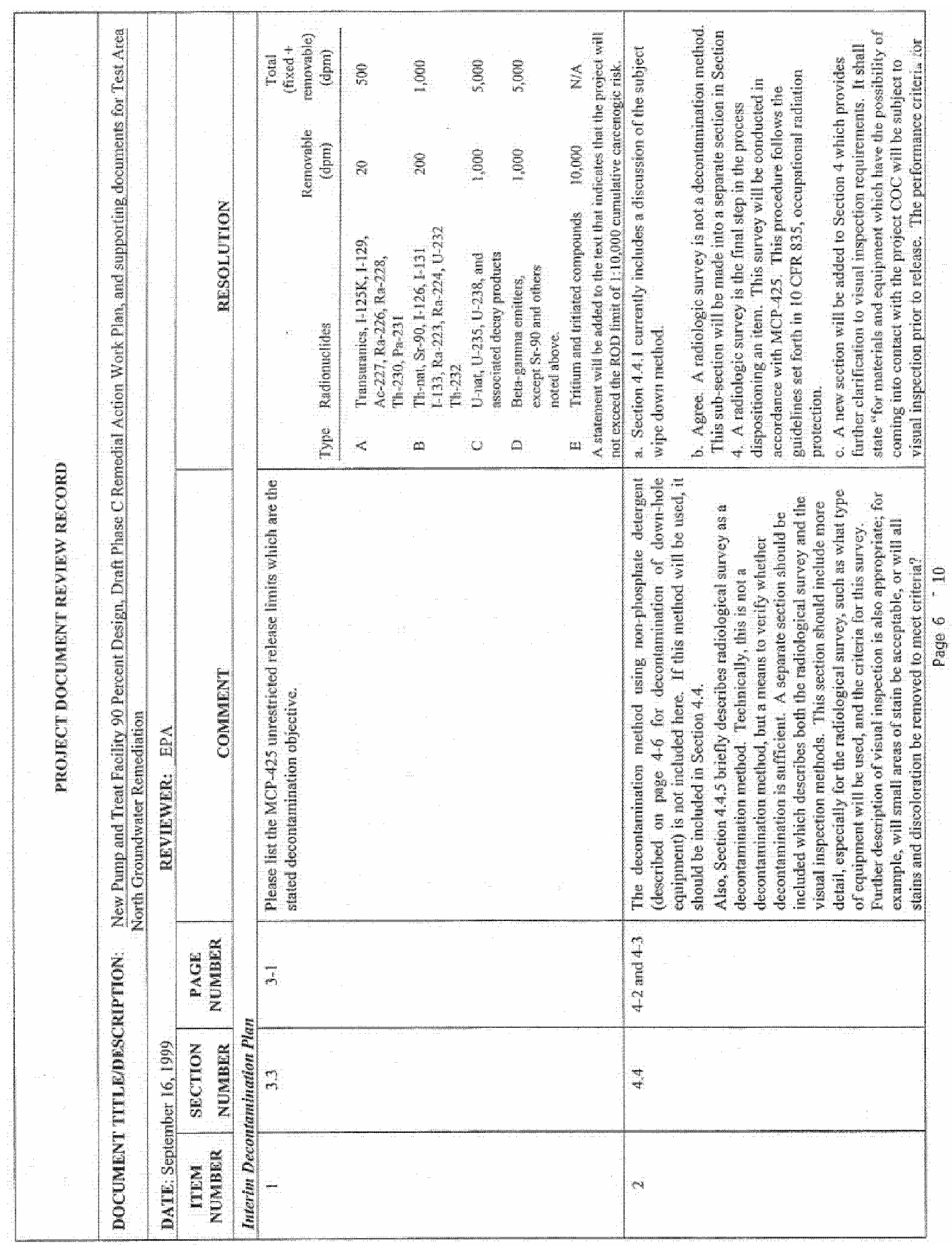




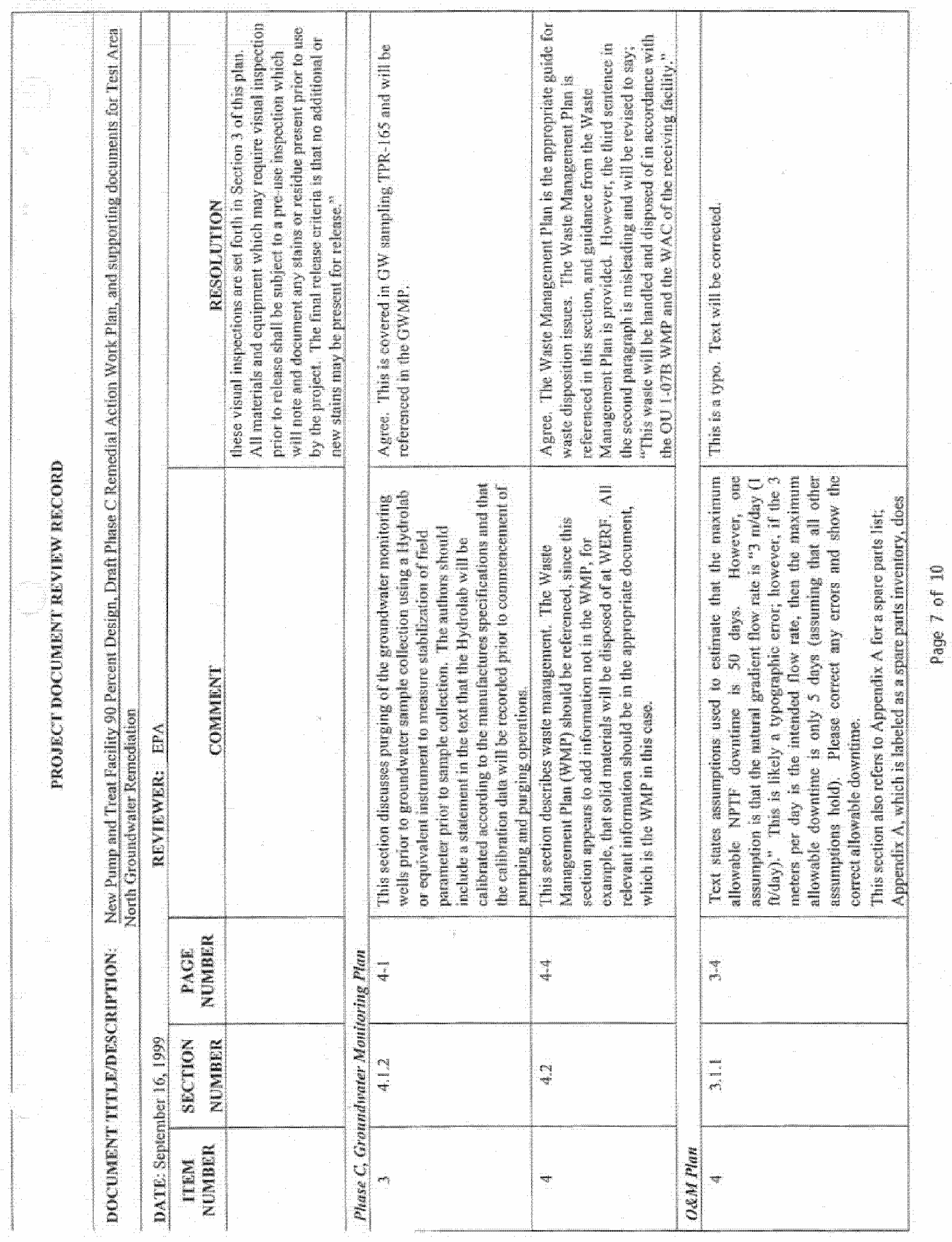




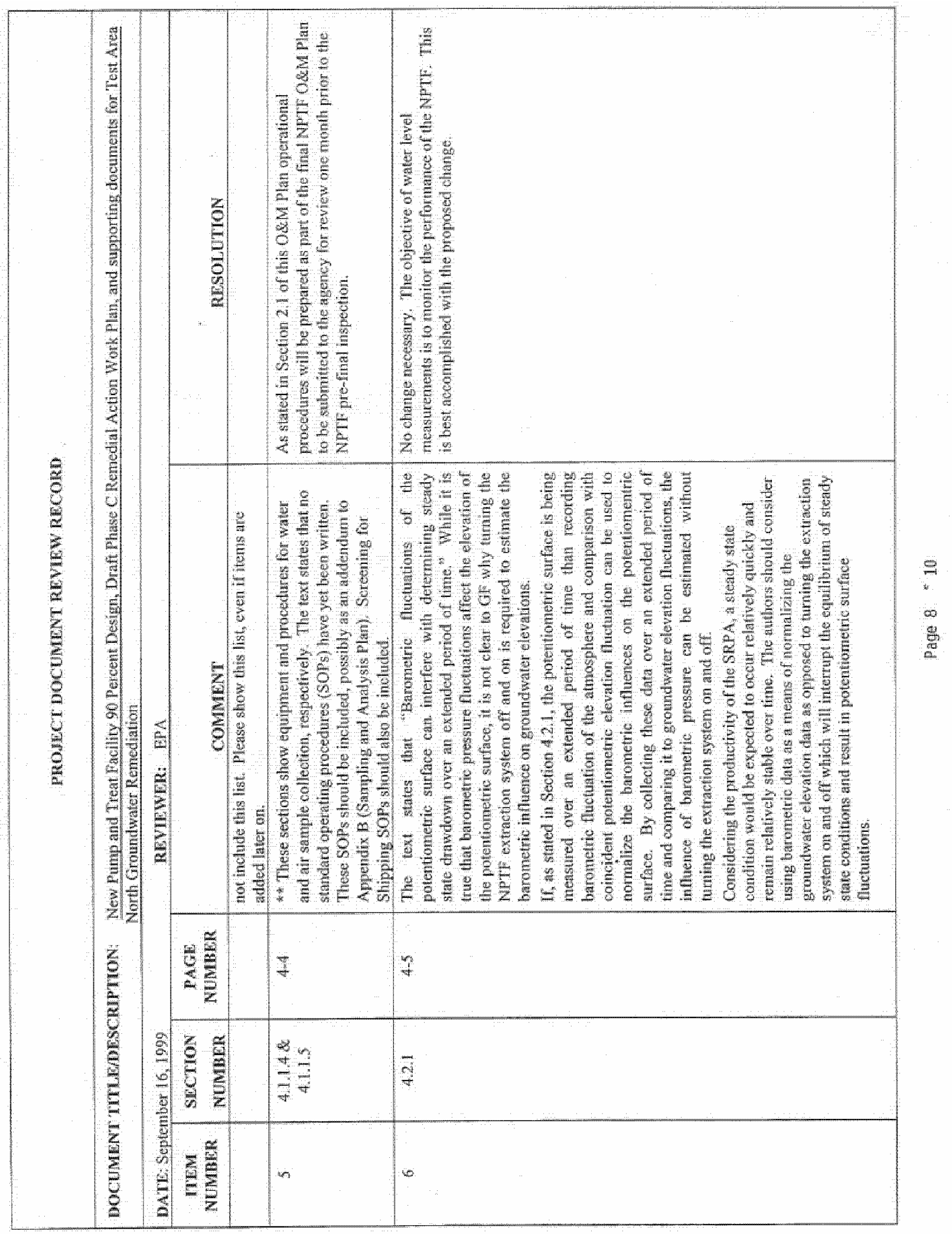




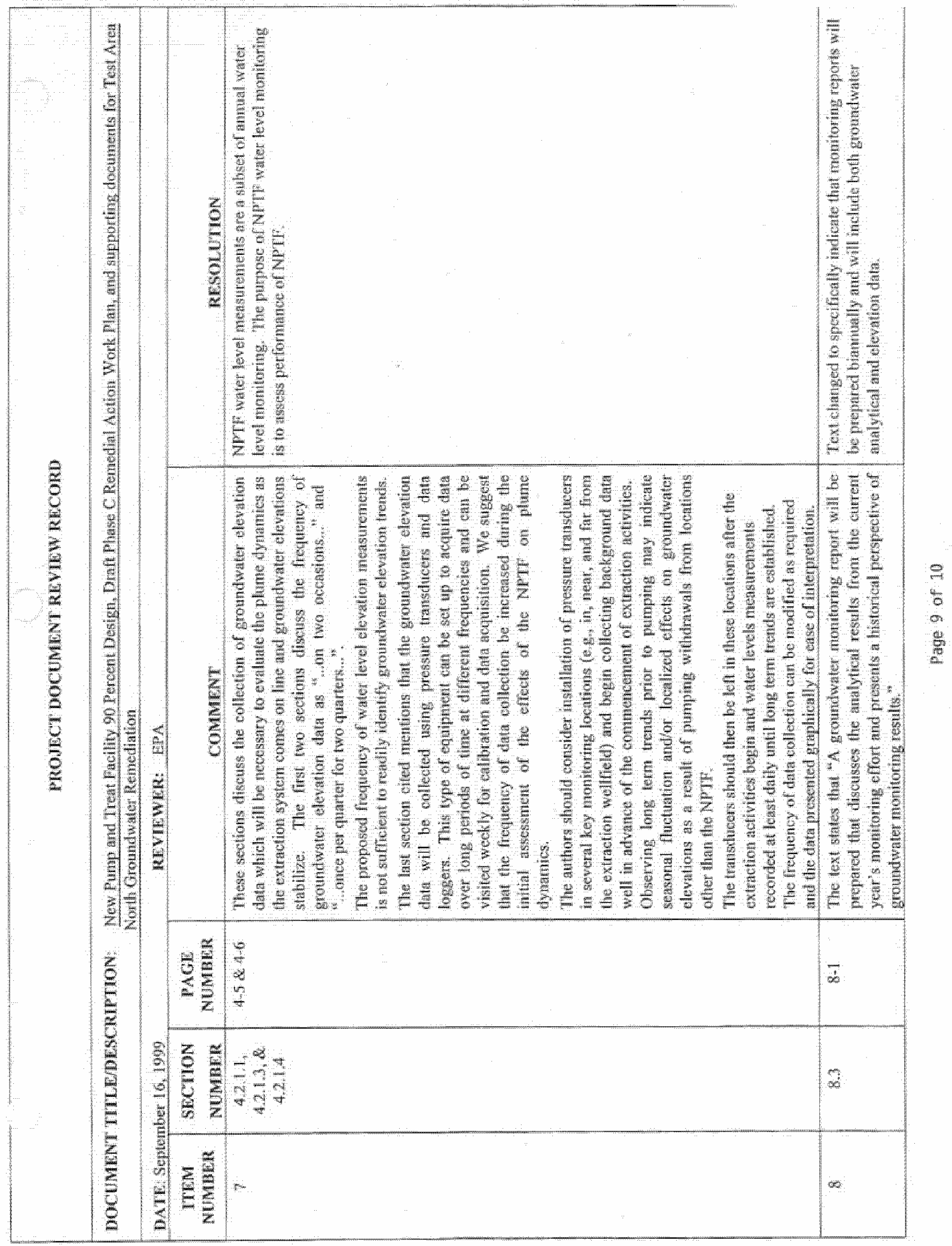




\begin{tabular}{|c|c|c|c|c|c|c|c|}
\hline \multirow{5}{*}{ 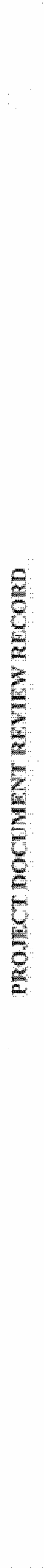 } & \multirow{5}{*}{ 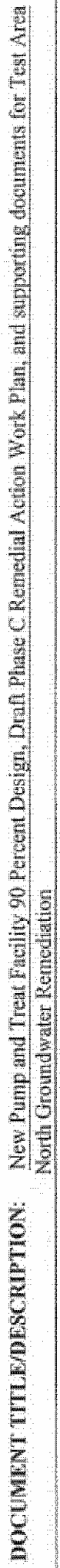 } & & $\frac{3}{3}$ & & 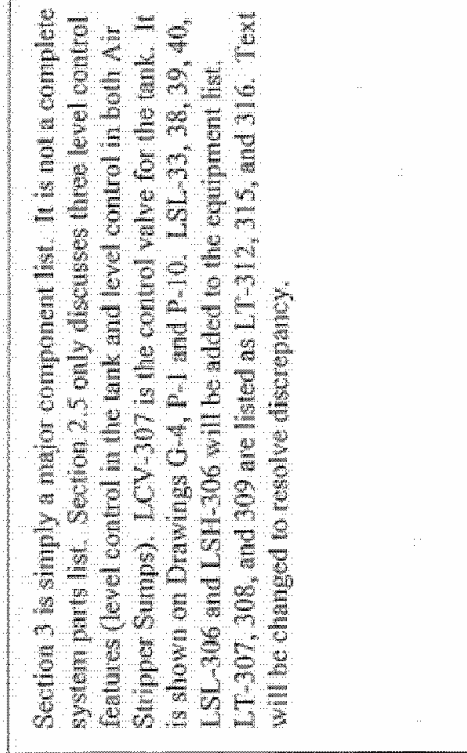 & 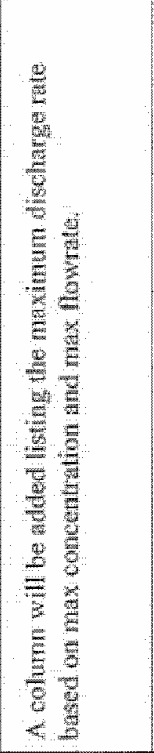 & 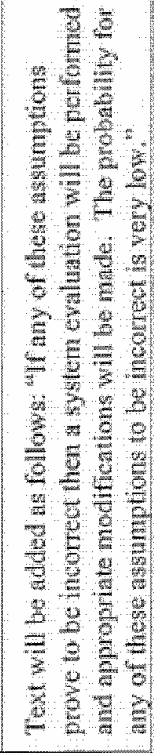 \\
\hline & & 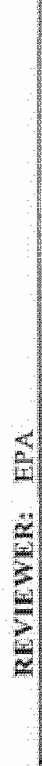 & $\frac{5}{3}$ & 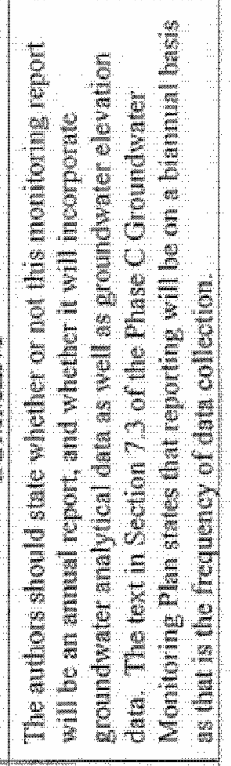 & 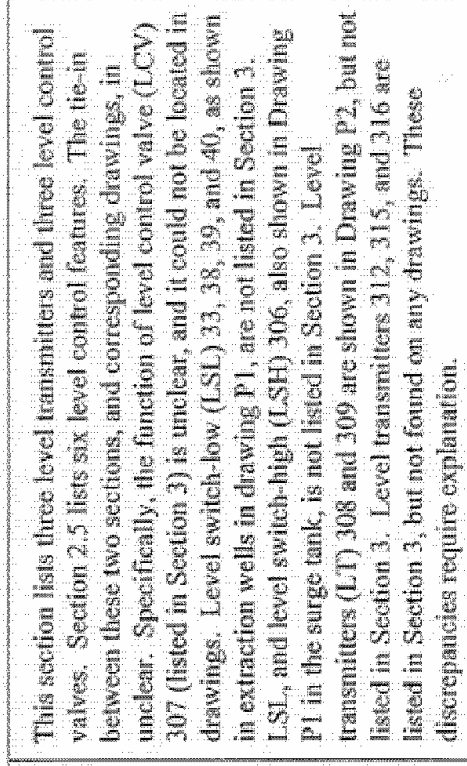 & 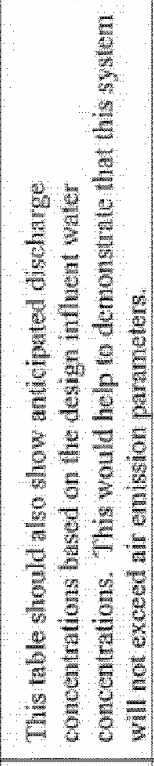 & 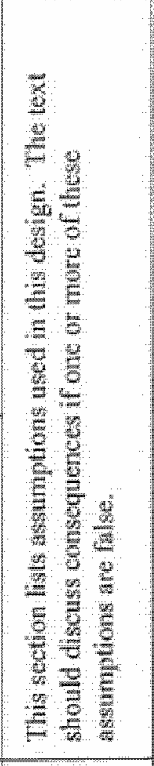 \\
\hline & & & $\frac{3}{2}$ & & $\frac{1}{3}$ & & 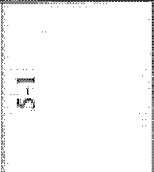 \\
\hline & & 0 & $\frac{5}{5}$ & & $m$ & $\frac{\bar{a}}{\frac{\pi}{3}}$ & $a$ \\
\hline & & 至 & $\frac{2}{3} \frac{5}{2}$ & & & 1 & $=$ \\
\hline
\end{tabular}

0
5
4
8 


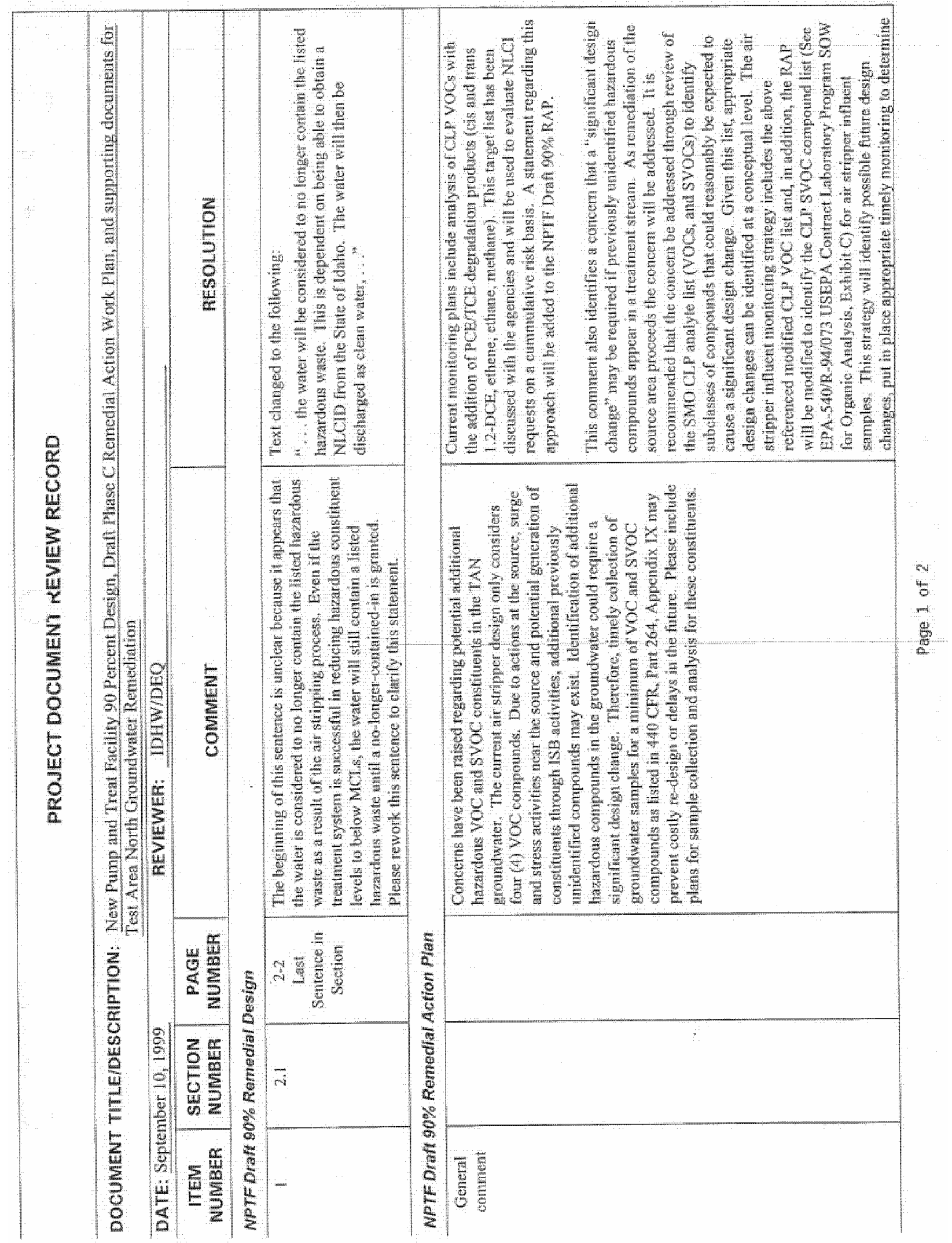




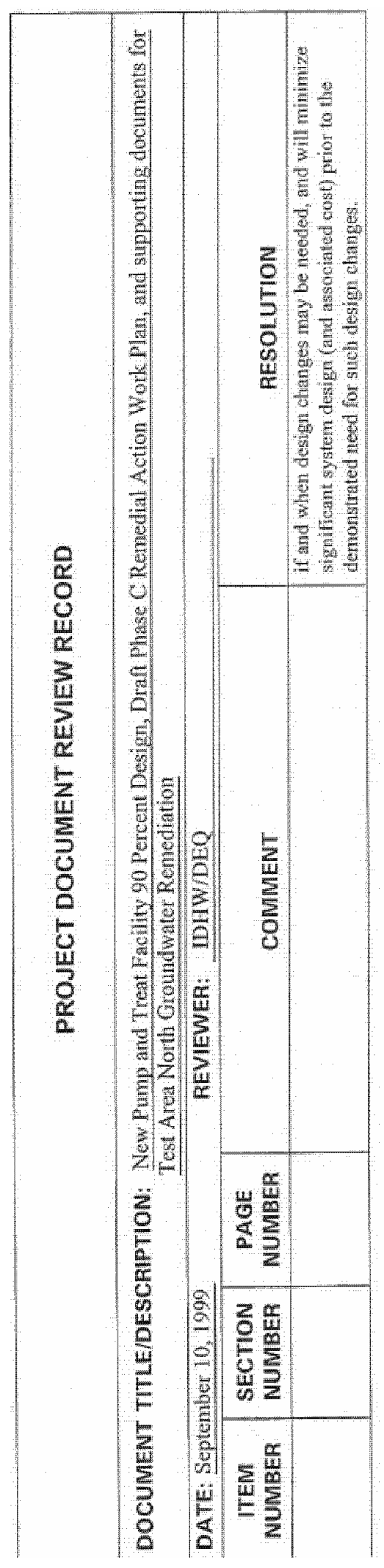

0
0
0 


\section{Appendix B-2 \\ Document Review Comments and Resolutions July 2003}


B-18 


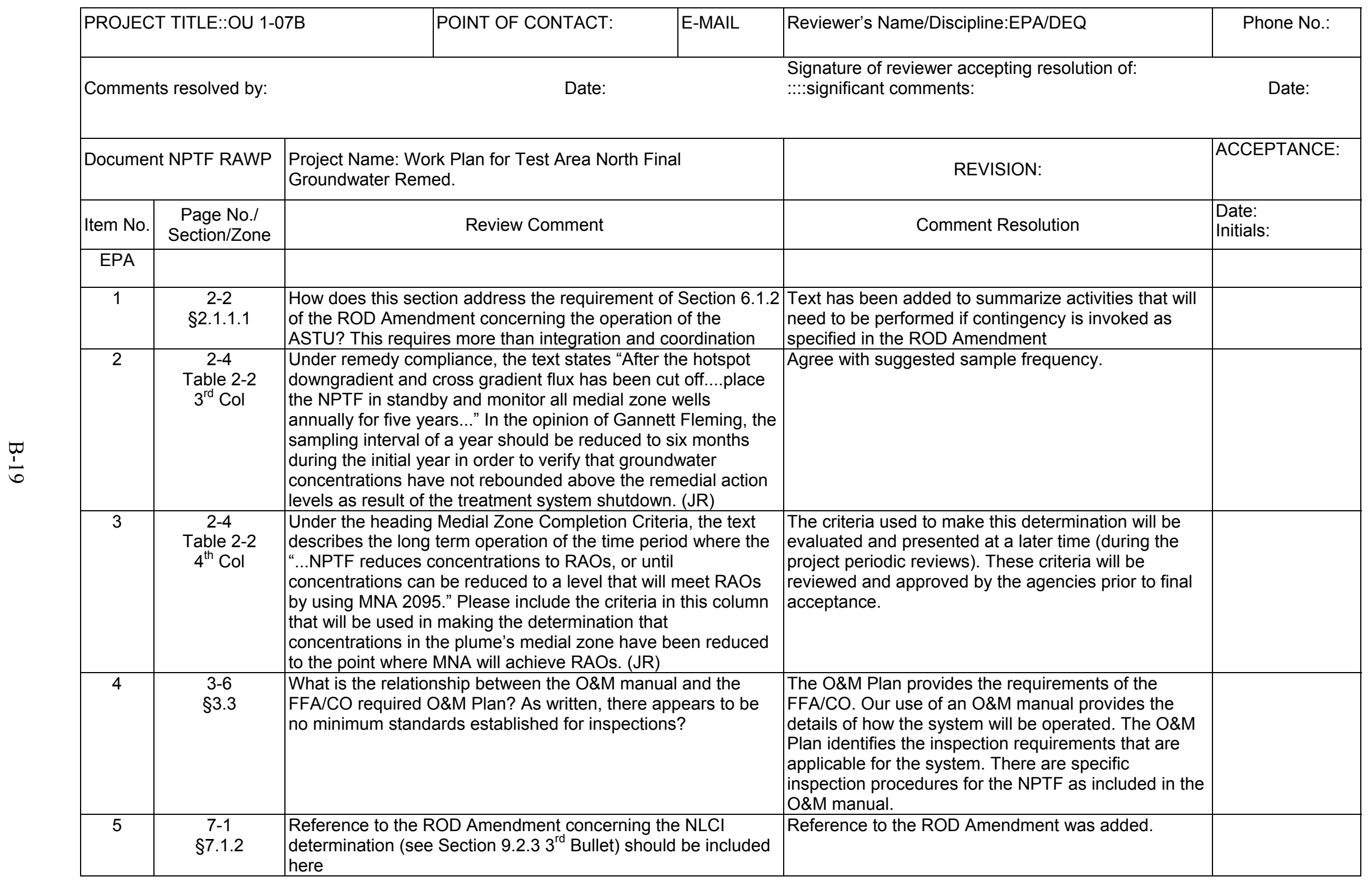




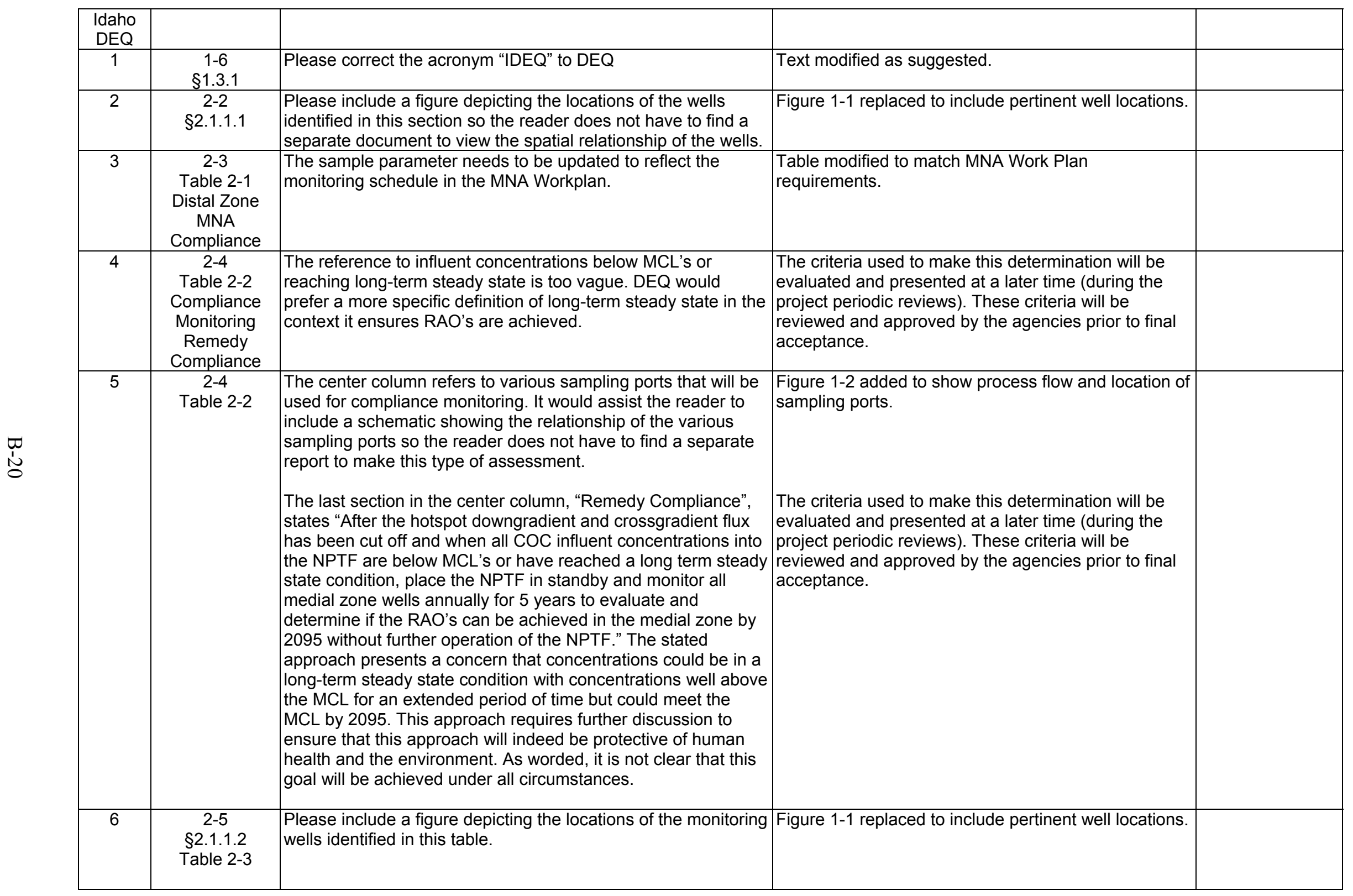




\begin{tabular}{|c|c|l|l|l|}
\hline 7 & $\begin{array}{c}4-5 \\
\S 4.3\end{array}$ & Please replace "IDEQ" with DEQ. & Text modified as suggested. \\
\hline $8-5$ & $\$ 4.3 .1$ & $\begin{array}{l}\text { Please verify in the last sentence that "proceeding" is the } \\
\text { intended term. It appears the proper term is processing. Please } \\
\text { modify as needed. }\end{array}$ & $\begin{array}{l}\text { Word should be processing. } \\
\text { Text changed. }\end{array}$ \\
\hline 9 & $\begin{array}{c}\text { A-13 } \\
\text { Appendix A } \\
\text { Table A-1 }\end{array}$ & $\begin{array}{l}\text { Although there is probably an issue with the ARARs noted in } \\
\text { the ROD, the proper citation should be the Idaho Ground Water } \\
\text { Quality Rule, which is IDAPA 58.01.11, and not the Drinking } \\
\text { Water Rule, which is a different citation. The agencies should } \\
\text { discuss a possible fix to this issue. }\end{array}$ & $\begin{array}{l}\text { Agree with issue and citation. Change will not be } \\
\text { incorporated at this time. This change will be noted } \\
\text { and possibly incorporated in the future if a change to } \\
\text { the ROD Amendment is ever made. }\end{array}$ & \\
\hline
\end{tabular}

